\title{
Modular Approach: Its Effect on Learners' Reading Attitude and Proficiency in the New Normal
}

\author{
ASLIMA M. MAROHOMBSAR 8 (D) \\ St. Michael's College, Address/Region: Quezon Avenue, lligan City, Region 10, Philippines \\ $\triangle$ Corresponding Author: ASLIMA M. MAROHOMBSAR, E-mail: a.marohombsar@my.smciligan.edu.ph
}

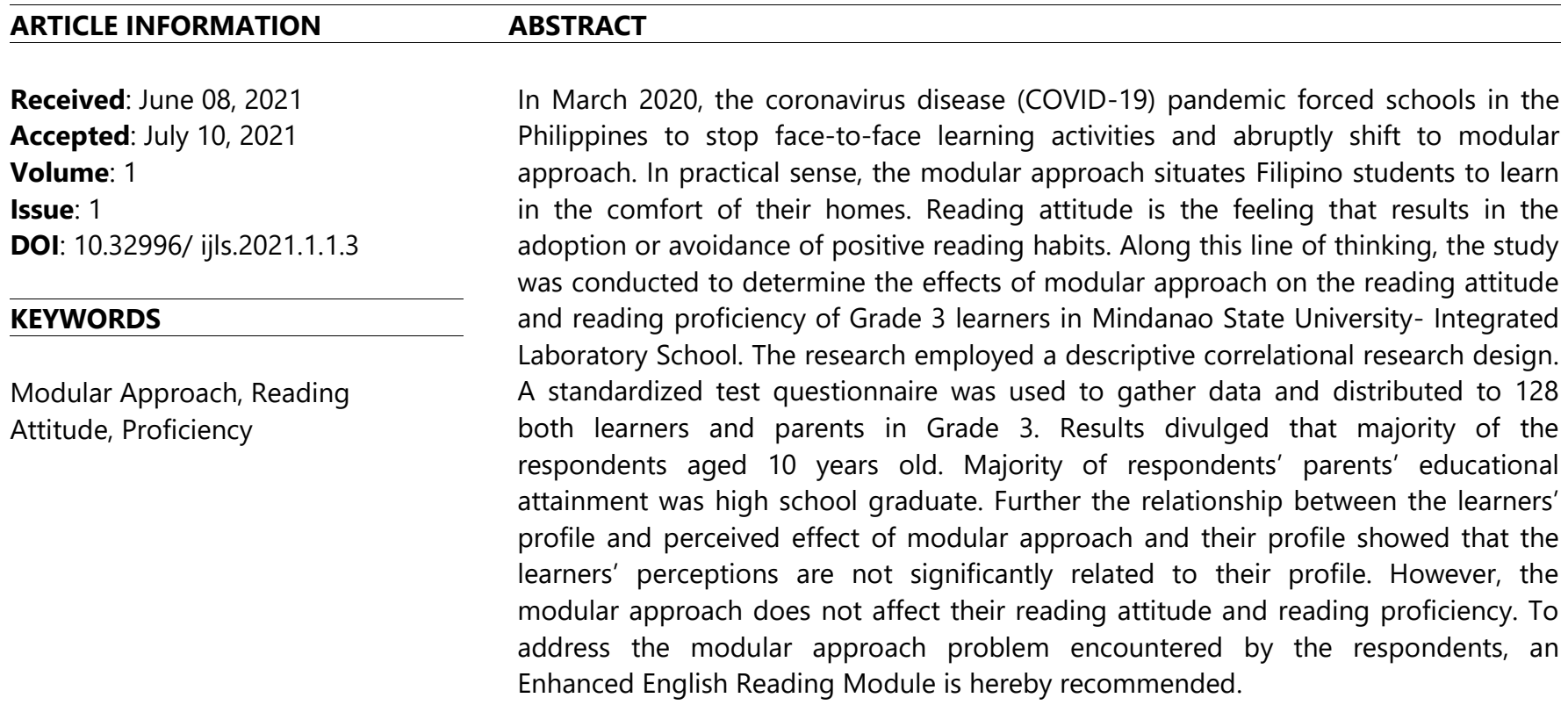

\section{Introduction}

The reading attitude and proficiency are seen to be the problem among the learners of MSU- Integrated Laboratory School. They experience difficult on reading of words. More students say they didn't understand much what is in the modules.

The fundamental difficulties that the students in MSU-Integrated Laboratory School have experienced are self-examining, helpless web association, absence of rest and time to answer every one of the modules because of the incredible number of exercises, interruptions, and absence of core interest. The present study intended to conduct a descriptive analysis on the reading attitude and proficiency of learners through modular approach.

The researcher focused her study on reading attitude and proficiency of the learners. McKenna, et. al (2013) found that females reported more positive attitudes for academic reading while males reported more positive attitudes toward recreational readings. This shows that text type and genre also influence reading attitude. Different reading attitudes may be observed in different sociocultural contexts. However, the literature reveals inconsistent results regarding the relationship between reading attitude and reading achievement. Based on the factorial report by Lee and Schallert (2014), the scales consisted of five factors, namely, cognitive attitudes, conative attitudes, negative affect, anxiety, and self-assessment. According to Lee and Schallert (2014), cognitive factor is related to the intellectual, practical, and linguistic values of reading; conative factor to the actual behavior of readers; and negative affect and anxiety to negative feeling about reading and self-assessment to students' perceptions of their reading competence

The researcher being faced with such concern have felt the urgency to conduct this study to look into the effectiveness of modular approach which could improve the reading attitude and proficiency of learners specifically the Grade 3 during the

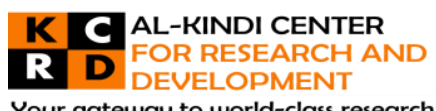

Your gateway to world-class research

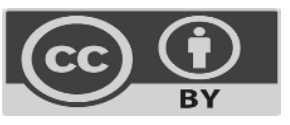

Published by Al-Kindi Center for Research and Development. Copyright (c) the author(s). This open access article is distributed under a Creative Commons Attribution (CC-BY) 4.0 license 
academic year 2020-2021. The researcher, likewise wanted a more accurate analysis of the effectiveness of modular approach in their reading attitude and proficiency.

Moreover, elementary learners need for strong, supportive relationships that enable students to take advantage of productive learning opportunities in cognitive, social, and emotional domains, plus additional supports physical, social, emotional, and academic needed to address individual circumstances that need attention at a moment in time to maintain a positive developmental trajectory Cantor, et. al (2018). They stress that all of these are interactive and interrelated and that these aspects of education must be designed to work together in a tightly integrated fashion.

Hence, the outcome of this study serves as the foundation in designing an Enhanced English Reading Module address the identified gaps based on the analysis made which would elevate the reading attitude and proficiency of the learners.

\subsection{Theoretical Framework}

This study on the modular approach its effect on learners' reading attitude and proficiency is anchored on the theory of constructivism, Schema Theory and the theory of Spady.

The Constructivism Theory of Perkins (1991) explains that individuals construct knowledge through interactions with their environment, and each individual's knowledge construction is different. So, through conducting investigations, conversations or activities, an individual is learning by constructing new knowledge by building on their current knowledge. Lave and Wenger (1991) argue that learning should not be viewed as simply the transmission of abstract and decontextualized knowledge from one individual to another, but a social process whereby knowledge is co-constructed; they suggest that such learning is situated in a specific context and embedded within a particular social and physical environment.

The Schema Theory by Carrell and Eisterhold (1983) point out, "one of the most obvious reasons why a particular content schema may fail to exist for a reader is that the schema is culturally specific and is not part of a particular reader's cultural background." It is thought that readers' cultures can affect everything from the way readers view reading itself, the content and formal schemata they hold, right down to their understanding of individual concepts. The fundamental principle of the schema theory assumes that written text does not carry meaning by itself. Rather, a text only provides directions for readers as to how they should retrieve or construct meaning from their own previously acquired knowledge an (2013). This theory is more likely related with the Cognitive Theory in which they both function in cognitive skills. Similarly with the cognitive theory the knowledge of a learner to a single word probably improves when the learner connect their prior knowledge to the new one and later on stored in their memory.

The theory of Spady (1998), all students can learn and succeed, but not on the same day in the same way; Successful learning promotes even more successful learning; Schools control many of the conditions that directly affect successful school learning; What and whether students learn is more important that when and how they learn; The purpose of school is to equip students for their lives after school; Students learn best when they have a clear picture of what is expected of them and when they are given adequate time to accomplish these things; and, In-depth learning of significant things is more useful than superficial learning about things of little consequence.

\subsection{Conceptual Framework of the Study}

The primary concern of the study is to find out the effect of modular approach on the learners' reading attitude and proficiency particularly in Mindanao State University- Integrated Laboratory School. As shown in figure 1 several variables were identified in this study: the respondents profile includes the age, time spent in reading, reading attitude and their parents' profile in terms of time spent in coaching learner in reading and the educational attainment of their parents. The reading attitude and proficiency of the respondents, and to the significant relationship between the profiles of the respondents to their Perceived Effect of Modular Approach to Reading Attitude and Proficiency.

Results from the study served as the bases in the formulation of enhanced English reading module. 
Learner's Profile

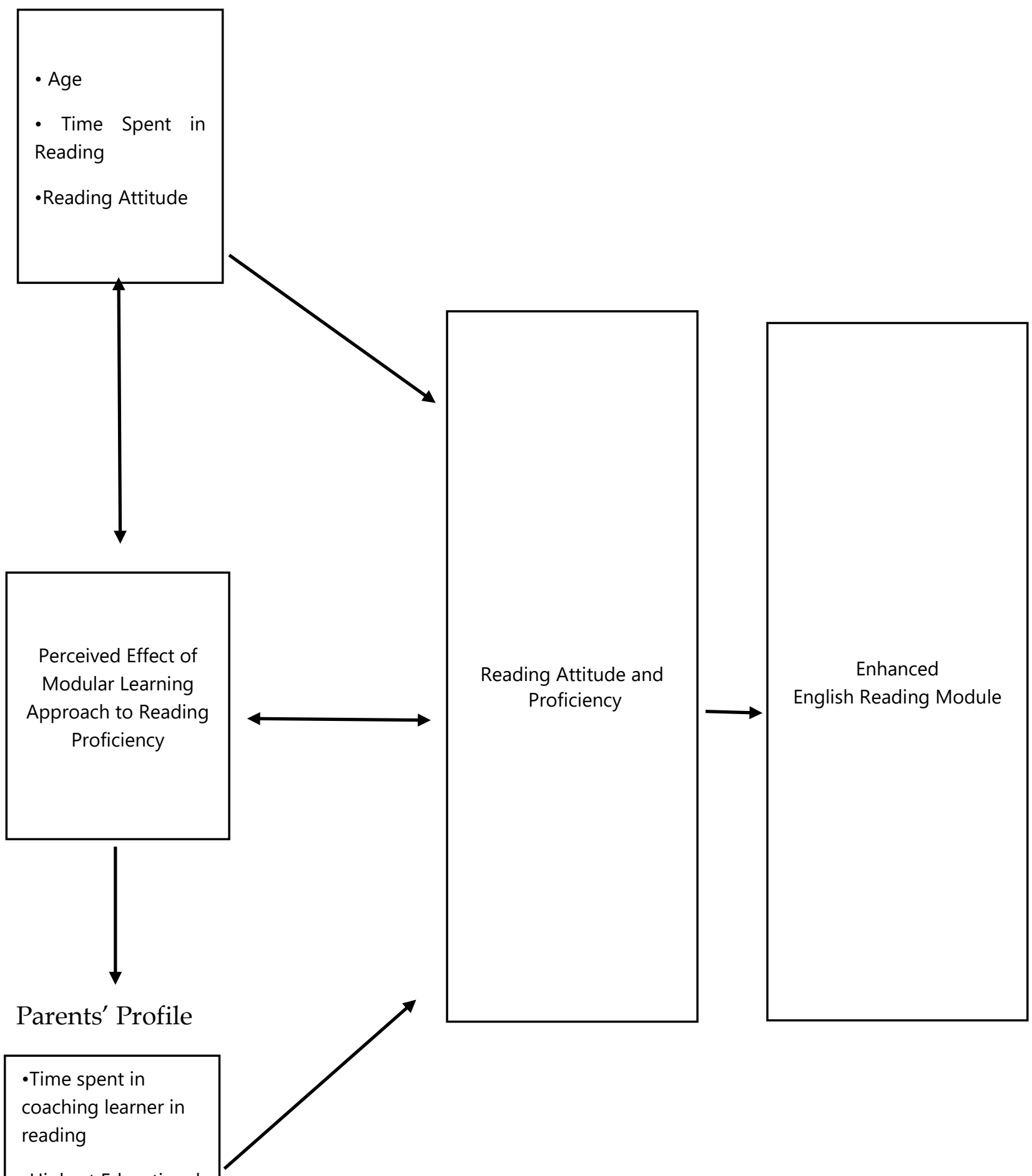

-Highest Educational

Attainment

Figure 1. Research Paradigm 


\subsection{Statement of the Problem}

This study aims to determine the pupils' reading attitude and proficiency in the New Normal. Specifically, it seeks to answer the following questions:

1. What is the profile of the respondents in terms of?
1.1. Age,
1.2. Time Spent in Reading, and
1.3. Reading Attitude

2. What is the profile of the parent- respondents in terms of:
2.1. Time spent in coaching; and
2.2. Highest educational attainment?

3. How do learners and parents perceived the effect of Modular Approach to reading proficiency of the learners?

4. Do the learners and parents' perceived effect of Modular Approach related to their profile?

5. What is the leaners' level of reading proficiency?

6. Do this perceived effectiveness of Modular Approach to the learners' reading proficiency related to the learners' actual reading proficiency?

7. How do learners' actual reading proficiency significantly differed when analyzed according to the learner's profile and parents' profile?

8. What enhanced English reading module maybe drawn from the findings of the study?

\subsection{Null Hypotheses}

Based on the statement of the problem, the following null hypothesis will be tested at 0.05 level of significance:

H01: There is no significant relationship between profiles of the respondents to their perceived effect of modular approach to reading proficiency;

HO2: There is no significant relationship between the profile of the respondents and their perceived effect of modular approach to reading proficiency.

\subsection{Significance of the Study}

This study aims to determine the reading attitude and proficiency of the learners through modular approach. The findings of this study may serve the following purpose that would contribute to the field of education particularly For the purpose of planning and designing programs and activities to improve the reading attitude and proficiency of the students.

School Administrators. This study gives straightforward data on the qualities and extraordinary abilities which may help them arrive at ideal turn of events. The aftereffect of this examination would help them in forming arrangements and make more thorough advancement plans and program that could improve the abilities of each understudy. Subsequently, become powerful whatever stage in life they are in.

Faculty Members. The result of this study can present relevant inputs and insights and will provide them additional knowledge on the Effectiveness of modular approach on reading attitude and proficiency.

Parents. They can understand their job and duty on how much significant their parental help and agreeable relationship with their youngsters that add to an effective improvement of their kids especially on understanding mentality and capability.

Future Researchers. This may serve as a reference and guide for the future researcher to further investigate the reading attitude and proficiency of the learners and to create an effective intervention that cater the problem on developing a modular approach. 


\subsection{Scope and Delimitation of the Study}

This study is limited to the effectiveness of modular approach to learner in Mindanao State University- Integrated Laboratory School, particularly the Grade 3 pupils of school year 2020- 2021.

The predictors of modular approach on its effect on reading attitude and proficiency of the learners taught through modular approach gained higher mean score in teacher made general comprehension-based test than students taught through traditional approach. Another variable in this study were the respondents' profile which includes, age, time spent in reading and reading attitude

The scope of this study is delimited to the Grade 3 pupils from the College of Mindanao State University- Integrated Laboratory School,

To assess the level of modular effectiveness, the researcher adapted the survey instrument to measure the effect of modular approach on reading attitude and proficiency of the learners.

\subsection{Definition of Terms}

For a better understanding of this study, the following terms are conceptually and operationally defined:

Modular Approach. This term refers to the emerging trend educational thinking that shifts traditional method of instruction to an outcome- based learning (Malik, 2012). In this study the term refers to the approach utilized by teachers to continuously teach learners in this pandemic time.

Reading Attitude. This term defined by Martinez (2017) as the feeling about reading that results in the adoption or avoidance of positive reading habits. In this study the term refers to the readings which improve self-improvement and self-satisfaction

Reading Proficiency. This term defined by Rogers (2019). Development Program. A program that explains how an intervention which could be a project, a program, a policy, or a strategy is understood to contribute to a chain of results that produce the intended or actual impacts. In this study, this term focuses on a plan of action on how to engage and develop the talents of students in enriching the business competence and to improve and sustain helpful skills to become more competitive in life.

\section{Review of Related Literature and Studies}

This chapter presents the review of the literature and studies considered relevant in the present investigation. This includes several published and unpublished literature and studies both local and foreign to give a deeper understanding of this study.

\subsection{Related Literature \\ Reading proficiency}

In cognizance of Jamal (2016), opined that obtaining new vocabulary words through reading any materials that learners of L2 have in hand as a reference is supplemental to attain more lexis. In return, learners can improve their grammatical construction of sentences. Furthermore, Yunjung (2011) mentioned that learners encounter a variety of familiar and unfamiliar words during reading and those words can be stored, elaborated and retained by a learner. It was asserted by Jones (2017) that reading comprehension is significantly linked to the development of one's vocabulary knowledge. Both students and teachers know that reading comprehension involve word recognition and lexical access. There's a significant relationship between vocabulary skills and reading comprehension.

However, it so exists those students face troubles on perusing perception as kids age, particularly among 3rd and 5th grades that the expression "4th grade droop" has been embraced to portray such wonders. There's presentation of new information, presence of various types, materials variety and contrasting reading purposes coming about to change between figuring out how to peruse and perusing to learn. It was then recommended that intuitive models of reading appreciation give the most suitable system to the investigation of both ordinary and cluttered perusing measure since understanding a composed language really requires base up word acknowledgment cycles and hierarchical perception measures Carter (2012).

Moreover, grasping sentences might be considered as a psychological cycle that is dependent both on grammatical and semantic parts of the sentence. The syntactic processors distinguish the sentence constituents while each word is connected to a syntactic expression. Reader should consolidate all the importance of each sentence that is resolved to be applicable to the theme, since perusing cognizance is a result of different assessments of the data that is introduced in the content. It suggests that reading perception won't be conceivable and attainable with only one data where the reader depend with. It is important to utilize the earlier information towards appreciating a sentence. 
Furthermore, it was proposed that immediate jargon guidance served to be a powerful encouraging methodology where an educator is using techniques that underlines understudy interest. Models are deciphering objective words, idea planning, managing the creation of understudy made jargon journals, inserting objective words in sentences and supporting a comprehension of target words with visual pictures.

\section{Reading Attitude}

In order for the students to shape into successful readers, they ought to have both the mastery and the will to peruse Seitz (2010). Thusly, when the students are introduced to reading materials whether or not it is inconvenient, reading is seen also over their agreement level, the students are undeniably to prevail because of their elevating viewpoint with respect to this subject Byro (2000). Concerning instructors' part, they often ignore the work of understudy points of view Seitz (2010). That is the explanation Tunde (2014) endorsed that teachers should reliably attempt to be capable facilitators of reading.

In support, Seitz (2010) said that students might be furnished with high premium and additionally testing exercises yet they may not stay drew in, protecting that students keep up upgraded uplifting outlooks to perusing so partners will be spurred in supporting the educational system completely Tunde (2014). Furthermore, Petcher (2010) demonstrated that it very well might be fundamental for guardians to show uplifting perspective towards perusing just as giving open doors in the home climate for the youngsters to show understanding conduct.

\section{Modular Approach}

The expression "module", acquired from software engineering, has gotten solidly settled in the fundamental jargon of teaching method. There are numerous subsidiaries with "module": measured innovation, particular technique, secluded methodology, secluded program, unit-particular and particular rating innovation. However, in every one of these cases it is alluded to the approach dependent on the improvement of instructive modules for various courses Kakurina (2012). The use of the modular approach in the instructive interaction adds to the arrangement of the accompanying issues: Improving the nature of the instructive cycle; Increasing freedom of students when arranging instructive cycle and execution of preparing programs; Making students gain and catch up on dynamic abilities during the time spent considering the instructive program Lopukhovan (2017).

Furthemore, Shuying (2013) referenced that once a reader show understanding toward the composed content with their experience information, it implies they were utilizing their diagram. Besides, when a reader could without much of a stretch relate their past information to the present or new words experienced in an understanding material and afterward, they likely grasp the entire content importance they have a functioning pattern.

\subsection{Related Studies}

In light of the investigation of Cruz-Deveza (2016) "Reading propensity as a factor of composing capability in English", she discovered that perusing itself is fundamentally connected with the composing abilities of a student since through it, one will gain some new useful knowledge in this manner enhancing his insight and have the option to communicate it recorded as a hard copy. That reading perception will be created as well as, it will improve its jargon and will study the composing mechanics like upper casing, indention, accentuation marks, or the English language itself. The reading abilities of leaners will assist them with being serious and connect unhesitatingly in any language learning action. Shockingly, some may discover trouble recorded as a hard copy with regards to English language especially the second language students. All things considered, there are loads of approaches to improve understanding abilities and that is through understanding magazines, news stories and surprisingly web-based media can be an apparatus. In addition, she moored the explanation of Vilches that some may have to draw in themselves to stir their premium with the goal for them to master and show anticipated abilities at their level.

The ability to read and write is a factor used to identify if one is educated. Hence, there was a study by Romeo (2017) "Oral reading skills of grade seven students", stating that learners in remote areas tend to show low performance. His study is focused on some public schools in Cagayan de Oro City where such issue is prevalent. He used the theory of Bruner on socio-cultural theory to determine the significant relationship of learner's experience through exposure to different reading activity and their reading performance. He added that DepEd had created Philippine informal reading inventory/ Phil-IRI, a program intended to improve reading skills of Filipino children. But it is only implemented for elementary level.

Similarly, with the study of Taga (2011)" The reading ability in English of the students of Bukidnon state University", it is concerned about how crucial reading is for learners, that students should be taught of how to comprehend and understand such use of language, for an instance. Accordingly, even if some students are already good in reading, they still have to continue improving their reading skills in order to improve their vocabulary and that reading does help them enrich their proficiency. Demographical profile of learners provides impact on the development on their reading abilities but still, interest and attitude towards reading greatly matter as well. 
In a recent research report, Kennedy et al. (2012) concluded that "a comprehensive model of early literacy development during the preschool and early school years strongly supports the view that a range of language and print related skills emerge in a mutually supportive fashion with development in one area promoting and supporting development in others" (p. 317). Moreover, several studies have confirmed that specific skills that are developed during preschool years could predict the reading performance at the primary school years Caravolas et al. (2014). Additionally, given that children are active users of technology in their everyday lives across a range of media, Korat (2010) suggested that well-designed technology tools carefully chosen by parents and teachers can provide young children with an additional efficient and enjoyable learning experience for reading development.

More so, a study done by Kalanduyan (2014) "Reading performance of grade six pupils in sultan Kudarat-I district, Maguindanao II division", emphasized that teacher's instructional competency will help improve the performance of a learner in reading. When English teachers are equipped with strategies and techniques that are essential in reading skills then it is not impossible for them to learn successfully. Reading is one of the most essential aspect in learning a language as most of the time, we deal with communication either verbally or non-verbally.

This present study used the above-mentioned related literature and studies to show effectiveness of modular approach to the reading performance of pupils in the new normal. The purpose of the researcher is to gain an understanding of the existing research and debates relevant to a particular topic or area of study, and to present that knowledge in the form of modular approach.

\section{Research Method}

This chapter presents the research design, locale of the study, respondents of the study, data gathering procedure and the statistical tools used for the analysis of the data.

\subsection{Research Design}

This study gathered and analysed data pertinent to the statement of the problem using descriptive-correlational method of research. Descriptive-correlational study attempts to determine whether and to what degree a relationship exists between two or more variables. It was adopted to analyse and interpret the data on the relationship of the modular approach to the learners reading attitude and proficiency.

In this study, the independent variables are the perceived effect of modular approach to reading attitude and proficiency along with their profile in terms of age, time spent in reading, reading attitude and their parents' profile in terms of time spent in coaching learner in reading, and their highest educational attainment. On the other hand, the dependent variable is the reading proficiency of the respondents. The researcher looked into the significant relationship between the profiles of the respondents to the perceived effect of modular approach to their reading proficiency.

\subsection{Locale of the Study}

This study was conducted in MSU- Integrated Laboratory School (MSU- ILS). The Integrated Laboratory School was originally known as the Laboratory Elementary School (LES). It was established on September 9, 1964, to meet the educational training needs of the children and dependents of the faculty and employees of the University. Later a pre- elementary education was created. Then, the University BOR Resolution No. 1522 Series of 1978, approved the expansion of the education program with four-year High School general Education. At present it is known as the Integrated Laboratory School (ILS). The ILS now performs two functions: as a laboratory school for the College of Education and other colleges and as a service function to the children and dependents of MSU faculty and other personnel.

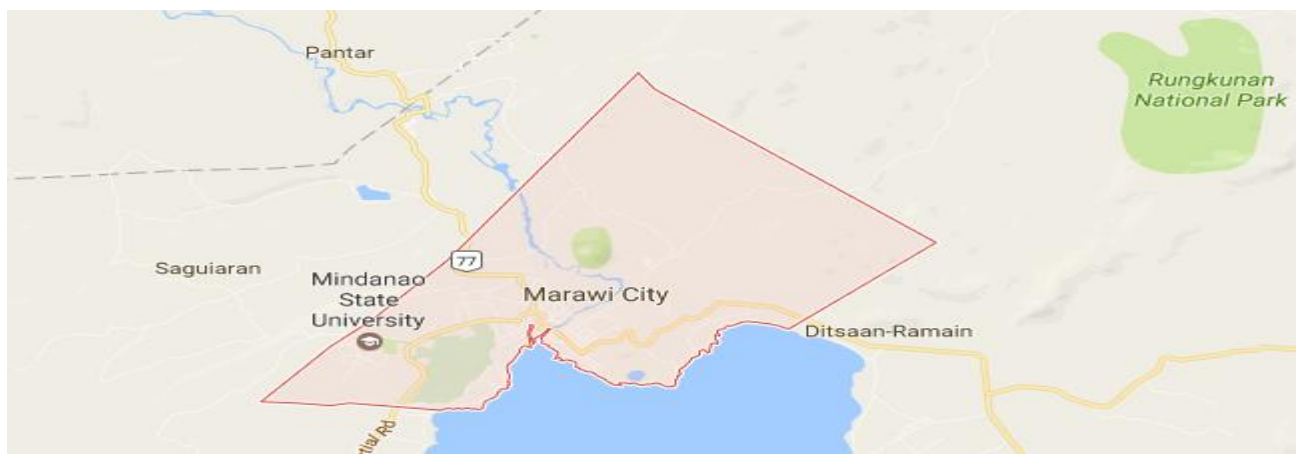




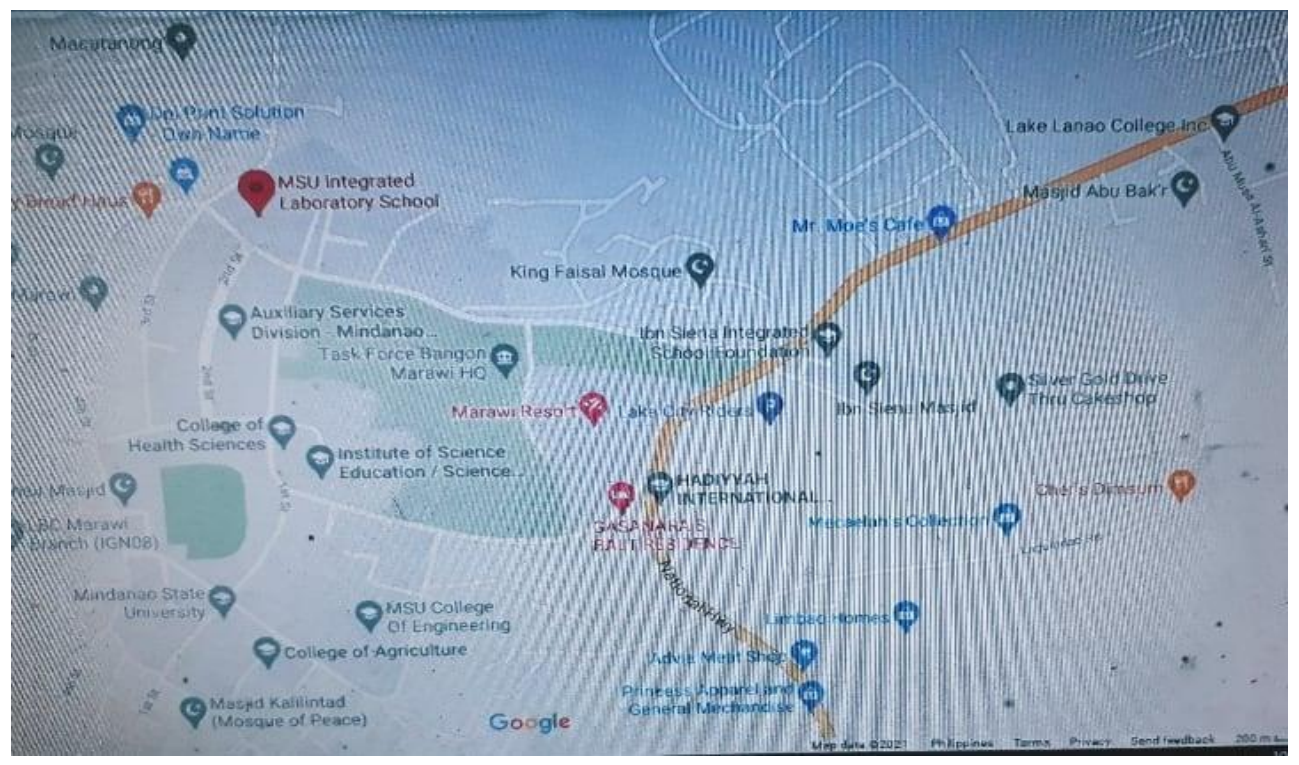

Figure 2. Map of MSU- ILS

\subsection{Respondents of the Study}

The respondents of this study were the Grade 3 learners sections Virgo and Sagittarius for the School Year 2020- 2021. A total of 64 learners with ages ranging from 9-11 majority of which are age 10 year old were the respondents of the study.

\subsection{Sampling Procedure}

The researcher used the simple random sampling method. According to Thomas (2020) simple random sample is a randomly selected subset of a population. In this sampling method, each member of the population in this study has an exactly equal chance of being selected respondents who are officially enrolled in Grade 3 Virgo and Sagittarius at Mindanao State UniversityIntegrated Laboratory School in the school year 2020-2021.

\subsection{Data Gathering Procedure}

This study utilized adapted standardized questionnaires in obtaining data from the respondents. According to Calderon (2004) questionnaires present uniform stimulus to all respondents and lead them to be more open and truthful even on sensitive and controversial topics.

With the permission sought from the Office of the Assistant Dean and the Principal of Mindanao State University- Integrated Laboratory School for the approval of the data gathering procedure of the study. Upon approval, the researcher personally administered the questionnaire to the Grade 3 pupils enrolled during school year 2020 - 2021 to assess their reading attitude and proficiency. Afterwards, collected questionnaires were tabulated and statistically analyzed with the other data. Furthermore, the researcher ensured strict confidentiality of the answers and results of the individual respondents.

\subsection{Instrument Used}

In this study, the researcher used three sets of research instruments namely: Reading proficiency (Phil- IRI), learner's profile (reading attitude), and structured questionnaire for determine the effect of modular approach to Reading proficiency of the respondents.

To get the necessary data for the realization of this study, the researcher used standardized test composed of a 6 -item test taken from the PHIL- IRI Reading Comprehension multiple type of test. The reading attitude test was originally a 10-item test in a multiple-choice format with two and four choices in each item. This implied a valid test to be administered for the participants. The results of the tests of learners served as basis for learners' reading attitude and proficiency.

\subsection{Scoring System}

The results of the Phil-IRI are analyzed quantitatively and qualitatively. The combined results of the word recognition and the answers to the comprehension questions will give the reading level of the student per passage: whether the respondent is in the independent, instructional or frustration level. The qualitative analysis consists of analyzing what types of miscues are made and 
describing the student's behavior while reading. Likewise, while the teacher administers the oral reading test, the respondent assesses whether the reading material matches the learner's reading performance. The teacher may give the student a reading material with a lower readability level if the respondent detects that the grade level reading material is too difficult for the student. The Phil-IRI reading test uses predetermined set of criteria in identifying the reading level of each student for each passage. These criteria include the percentage of word recognition accuracy and the percentage of correct answers to comprehension questions adapted from Johnson et. al (1987). Table A shows the table of Percentage for Comprehension Scores. Thus, the table below indicates the scoring and its descriptions to be utilized.

Table A : Scoring System Procedure and Interpretation of the Reading Attitude Instrument

\begin{tabular}{llll}
\hline Rating & Scoring Scale & Qualitative Description & Qualitative Interpretation \\
\hline 4 & $3.25-4.00$ & Happy & Very Positive \\
3 & $2.50-3.24$ & Slightly Happy & Positive \\
2 & $1.75-2.49$ & Mildly Upset & Negative \\
1 & $1.00-1.74$ & Very Upset & Very Negative \\
\hline
\end{tabular}

The scoring guide will be used to interpret the score obtain by the respondents on the reading attitude survey scoring test and its corresponding description with the score interval.

\subsection{Validity of Instruments}

The instrument has three parts: part I is the Learner's Reading Proficiency -PHIL IRI, part II Learner's Profile- Reading attitude, and part III is structured questionnaire which have undergone rigid construct validation and reliability test done by Dr. Anecito B. Naval using Cronbach's Alpha. In order for the data to be reliable, 64 Grade 3 learners from Mindanao State UniversityIntegrated Laboratory School are selected by random answered the Learners' Reading Proficiency while the Learners' Reading Attitude instrument was assessed by the 5 teachers selected by random from Mindanao State University- Integrated Laboratory School.

The part I of the instrument was adapted from PHIL - IRI reading comprehension. The questionnaire was modified and simplified by the researcher to suit the Grade 3 learners in MSU- ILS. The part II of the instrument was also adapted from the Elementary Reading Attitude Survey by McKenna (1990). The part III of the instrument is structured questionnaire, it is an Open- ended questions, the researcher simply ask a question and allow participants to answer in whatever way they choose. During the data gathering, the researcher administered the questionnaire to the participants that were 5 pupils in the morning and 5 pupils in the afternoon. Healthy protocols were strictly followed. Further, the general directions in answering the questionnaire were explained.

\subsection{Statistical Treatment of Data}

The researcher employed a quantitative method of treating the data for analyses suited according to the research problem mentioned in Chapter 1. These are basic and inferential non-parametric statistical tools appropriate to the nature of the data sets gathered and satisfied the necessary assumptions of the tests selected. These are the following:

Frequency and Percent. These basic descriptive statistical tools were used to describe the learner and parent respondents' profiles. These are appropriate statistical tools to answer and analyze research problem number one (1) and research problem number (2) as stated in the statement of the problem. These statistical tools were also utilized to account for the responses of the respondents' perceived effect of the modular learning approach on reading proficiency. This is because the profiles of the respondents and other variables considered under this study as one of the variables were categorical. Thus, to describe them the most frequent observation is considered using frequency and percentage equivalent.

Mean and Standard Deviation. These basic statistical tools were used to describe and measure the average location and variation of the learner-respondents' self-assessment on their reading attitude and reading proficiency. These descriptive statistics are appropriate to answer and analyze the research problems in number one (1) specifically in the sub-problem on the reading attitude and problem number five (5) as mentioned in the statement of the problem since these variables are operationally measurable quantitatively. 
Thematic Analysis. This method of analyzing the transcript of interviews from both learners and parents. This approach is appropriate to answer the research problem stated in number two (3) since the data obtained were qualitative responses of the respondents. The purpose is to uncover the respondents' perceived effect of the modular learning approach on reading proficiency.

Cramer's V. This non-parametric test was utilized to answer the research problems as stated in problem number four (4) and number six (6). This was conducted to analyze the extent of the relationship between learners' and parents' perceived effectiveness of the modular learning approach and their profile. This was done because the variables involved in this analysis were categorical and were measured through frequency counts and percentages.

Mann-Whitney $\mathbf{U}$ Test and Kruska-Wallis $\mathbf{H}$ Test. These non-parametric statistical tools were utilized to answer and analyze research problem number seven (7). These tools are more appropriate since it this not require the normality of distribution of the data set of the reading proficiency. The result of the normality test is presented below.

Table B : Test for Normality Distribution of the Learners' Reading Proficiency Data Set

\begin{tabular}{|c|c|c|c|}
\hline \multirow{2}{*}{ Data Set (Variable) } & \multicolumn{3}{|c|}{ Shapiro-Wilk } \\
\hline & Statistic & $\mathrm{df}$ & p-value \\
\hline Reading Proficiency & .884 & 64 & $<.001$ \\
\hline
\end{tabular}

Shapiro-Wilk test yielded a highly significant result of the data set of the reading proficiency of the learners $(W=.884, p<.001)$. This led the researcher to reject the null hypothesis stating that the data sets are normally distributed. This means that the normality distributions are not satisfied. This warrants the researcher to utilize the Mann-Whitney $\mathrm{U}$ test and Kruskal-Wallis $\mathrm{H}$ test in testing significant differences in the mean scores of the respondents' reading proficiency when analyzing between and among their demographic profiles.

\section{Presenation, Analysis and Interpretation of Data}

This chapter presents, analyzes and interprets the data and discloses all results based from the data gathered. The table are arranged in the same order as they were presented in the statement of the problem in chapter 1.

Problem 1: What is the profile of the respondents in terms of age, availability of books at home, time spent in reading, parents involvement in reading at home, and reading attitude?

Table 1.1: Frequency and Percentage Distribution of the Learner-Respondents Profile $(n=64)$

\begin{tabular}{|c|c|c|c|}
\hline Profile & & Frequency & Percent \\
\hline \multirow[t]{3}{*}{$\overline{\text { Age }}$} & 9 years old & 20 & 31.3 \\
\hline & 10 years old & 38 & 59.4 \\
\hline & 11 years old & 6 & 9.4 \\
\hline \multirow[t]{2}{*}{ Availability of Books at Home } & None & 12 & 18.8 \\
\hline & Available & 52 & 81.3 \\
\hline \multirow[t]{2}{*}{ Time Spent in Reading } & A little & 49 & 76.6 \\
\hline & A lot & 15 & 23.4 \\
\hline \multirow[t]{3}{*}{ Parents Involvement in Reading At Home } & Reading at Home with Parents & 49 & 76.6 \\
\hline & Talk About the Meaning of Story & 47 & 73.4 \\
\hline & Ask What is Happening in the Story & 46 & 71.9 \\
\hline
\end{tabular}

Table 1.1 shows the Frequency and Percentage Distribution of the Learner-Respondents Profile $(n=64)$. 
As shown, the majority of the respondents or 59.4 percent were 10 years old. In terms of Availability of Books at Home, there were 81.3 percent available books. In terms of Time Spent in Reading, there were 76.6 percent who spent time in reading. There were 76.6 percent in reading at home with parents. Majority of these respondents was at the right age suited for Grade 3.

The finding of the study conform to the investigation of Pedrosa et al. (2014), he stress also on the possibility of the effect of age to those learner interacting with other learners too. This finding of Pedrosa et al. (2014) is likely related with the reports of Carter (2012) claimed that the age of the learner has a significant relationship with reading comprehension.

Table 1.2 : Reading Attitude of the Learners in Terms of Recreational

\begin{tabular}{|c|c|c|c|c|}
\hline \multicolumn{2}{|c|}{ Indicators } & \multirow{2}{*}{$\begin{array}{l}\text { Mean } \\
3.06\end{array}$} & \multirow{2}{*}{$\begin{array}{l}\text { SD } \\
.974\end{array}$} & \multirow{2}{*}{$\begin{array}{l}\begin{array}{l}\text { Qualitative } \\
\text { Interpretation }\end{array} \\
\text { Slightly Happy }\end{array}$} \\
\hline 1. & How do you feel when you read a book on a rainy Saturday? & & & \\
\hline 2. & How do you feel when you read a book in school during free time? & 2.95 & .933 & Slightly Happy \\
\hline 3. & How do you feel about reading for fun at home? & 3.37 & .882 & Slightly Happy \\
\hline 4. & How do you feel about getting a book for a present? & 3.05 & 1.061 & Slightly Happy \\
\hline 5. & How do you feel about spending free time reading? & 3.13 & .724 & Slightly Happy \\
\hline 6. & How do you feel about starting a new book? & 3.09 & 1.019 & Slightly Happy \\
\hline 7. & How do you feel about reading during summer vacation? & 2.66 & 1.250 & Slightly Happy \\
\hline 8. & How do you feel about reading instead of playing? & 2.48 & 1.221 & Mildly Upset \\
\hline 9. & How do you feel about going to a bookstore? & 3.52 & .690 & Slightly Happy \\
\hline \multirow[t]{2}{*}{10.} & 10. How do you feel about reading different kinds of books? & 3.19 & .794 & Slightly Happy \\
\hline & Over-all Mean & 3.05 & .438 & Slightly Happy \\
\hline
\end{tabular}

Table 1.2 shows the Reading Attitude of the Learners in Terms of Recreational. As shown, the lowest mean which the learners feeling about reading instead of playing has a mean of 2.48 were the qualitative interpretation was 1.221 . The results shows that most learners was slightly happy. It implies that learners at young age wanted to play a lot than reading.

This result was substantiated by the study of oxford learning centers, Inc., 2017, the key to encouraging reading habits in kids is reading with them at home from a young age. By reading together often, your child will learn firsthand the joys reading can bring, helping him or her develop a motivation to read. However, every student learns and processes information differently. This means that some children may have a natural love of reading.

Furthermore, parents often complain that their early readers can read, but just don't seem interested in doing so. Most kids go through this stage, but you can help to keep it a brief one. The child's problem, of course, is that he can read simple books, but his imagination craves more developed plots and characters. Those books are agonizing work, with too many words he doesn't know. The labour distracts him from the story. The solution? He needs his parents to keep reading to him, to keep him fascinated with the secrets of books. That's what will motivate him to do the hard work to become a proficient reader Reardon (2012).

Table 1.3: Reading Attitude of the Learners in Terms of Academic Reading

\begin{tabular}{llrl}
\hline Indicators & Mean & SD & $\begin{array}{c}\text { Qualitative } \\
\text { Interpretation }\end{array}$ \\
\hline $\begin{array}{l}\text { 1. How do you feel when the teacher asks you questions about what you3.14 } \\
\text { read? }\end{array}$ & .710 & Slightly Happy \\
2. How do you feel about doing reading workbook pages and2.61 & .884 & Slightly Happy \\
3. $\quad$ How do you feel about reading in school? & 3.06 & .614 & Slightly Happy \\
4. How do you feel about reading your school books? & 3.28 & .701 & Slightly Happy \\
5. How do you feel about learning from a book? & 3.38 & .577 & Slightly Happy \\
\hline
\end{tabular}


6. How do you feel when it's time to reading class?

7. How do you feel about the stories you read in reading class?

8. How do you feel when you read out loud in class?

9. How do you feel about using a dictionary?

10. How do you feel about taking a reading test?

$\begin{array}{lll}2.84 & .781 & \text { Slightly Happy } \\ 3.23 & .684 & \text { Slightly Happy } \\ 2.37 & 1.047 & \text { Mildly Upset } \\ 2.84 & .963 & \text { Slightly Happy } \\ 2.58 & .973 & \text { Slightly Happy } \\ \mathbf{2 . 9 3} & . \mathbf{2 5 5} & \text { Slightly Happy }\end{array}$

Table 1.3 shows Reading Attitude of the Learners in Terms of Academic Reading. The results showed that majority of the respondents were slightly happy with over- all mean of 2.93 percent. Another thing that could perceive on this finding is that most of the respondent's reading attitude in terms of academic reading was slightly happy. It implies that the respondents are slightly happy also when they read out loud in class.

According to Lindsay (2010), students' attitudes toward reading were found to be multidimensional and challenging to assess.

Table 1.4: Summary of the Reading Attitude of the Respondents

\begin{tabular}{|c|c|c|c|c|c|c|c|c|c|c|c|c|}
\hline \multirow{2}{*}{ Scoring Scale } & \multicolumn{4}{|c|}{$\begin{array}{l}\text { Recreational } \\
\text { Reading }\end{array}$} & \multicolumn{4}{|c|}{$\begin{array}{l}\text { Academic } \\
\text { Reading }\end{array}$} & \multicolumn{4}{|c|}{$\begin{array}{l}\text { Reading Attitude } \\
\text { (Full Scale) }\end{array}$} \\
\hline & $f$ & $\%$ & $M$ & QI & $f$ & $\%$ & $M$ & QI & $f$ & $\%$ & $M$ & QI \\
\hline $3.25-4.00$ & 26 & 40.6 & 3.48 & $V P$ & 7 & 10.9 & 3.36 & $V P$ & 15 & 23.4 & 3.38 & $V P$ \\
\hline $2.50-3.24$ & 31 & 48.4 & 2.87 & $P$ & 57 & 89.1 & 2.88 & $P$ & 49 & 76.6 & 2.87 & $P$ \\
\hline $1.75-2.49$ & 7 & 10.9 & 2.26 & $N$ & & & & & & & & \\
\hline Total & 64 & 100.0 & 3.05 & $P$ & 64 & 100.0 & 2.93 & $P$ & 64 & 100.0 & 2.99 & $P$ \\
\hline
\end{tabular}

f - Frequency; M - Mean; Qualitative Interpretation (QI): VP - Very Positive; $\boldsymbol{P}$ - Positive; $\mathbf{M U}$ - Negative

Table 1.4 shows the Summary of the Reading Attitude of the Respondents. The result of analysis found that the lowest total score was the academic reading of the respondents. It implies that the respondents are limited proficiency in English, those from homes where the parents' reading levels and practices are low.

According to, Cadeliña (2013), attitude refers to a way a person views something or tends to behave towards it; it refers to either positive or negative respond through the initial response of the behaviour.

Problem 2: What is the profile of the respondents in terms of highest educational attainment, time spent in coaching reading, and learners involvement in reading at home?

Table 2: Frequency and Percentage Distribution of the Parent-Respondents Profile $(n=64)$

\begin{tabular}{|c|c|c|c|}
\hline Profile & & Frequency & Percent \\
\hline \multirow[t]{2}{*}{ Highest Educational Attainment } & Elementary Level/ Graduate & 10 & 15.4 \\
\hline & $\begin{array}{l}\text { College level/ } \\
\text { Graduate }\end{array}$ & 41 & 63.1 \\
\hline Time Spent in Coaching Reading & 15 minutes & 57 & 87.7 \\
\hline \multirow[t]{2}{*}{ Learners Involvement in Reading At Home } & Talk About the Meaning of Story & 63 & 96.9 \\
\hline & Ask What is Happening in the Story & 51 & 78.5 \\
\hline
\end{tabular}


Table 2 shows the Frequency and Percentage Distribution of the Parent-Respondents Profile $(n=64)$. The result of analysis found that the most of the respondents are college level/graduate since there were 41 or $63.1 \%$ of the total respondents. On the other hand the time spent in coaching reading there were 87.7 percent who spent about 15 minutes. And 96.9 percent talks about the meaning of the story. It implies that the respondents' parents were really involved when they coach their learners reading attitude and proficiency.

According to Cheadle and Amato (2011), high-income and highly educated parents are more likely to be involved in their child's education, which is a key factor students' educational success.

Problem 3: How do learners and parents perceived the effect of Modular Learning Approach to reading proficiency of the learners?

Table 3.1: Learners' Perceived Effect of Modular Approach to the Reading Proficiency of the Learners

\begin{tabular}{|c|c|}
\hline Questions & Responses \\
\hline $\begin{array}{l}\text { 1. How do you find } \\
\text { Modular Approach and } \\
\text { why? }\end{array}$ & 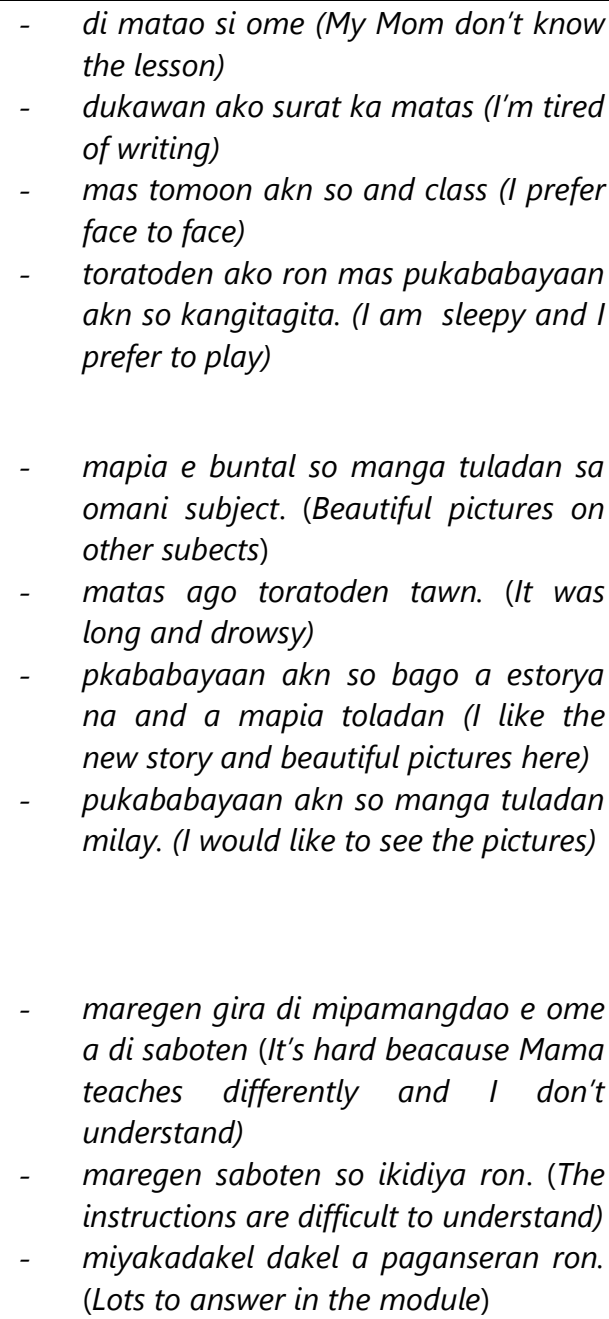 \\
\hline
\end{tabular}

\section{Theme}

Boring

Interesting

Difficult 
Table 3.1: Learners' Perceived Effect of Modular Learning Approach to the Reading Proficiency of the Learners (cont'n.)

\section{Questions}

2. Do you think it beneficial to you? Yes or No? Why?
Responses

adun a oras akun ko ka anser (I have

a lot of time to answer).

- adun pukasuwaa akn ron (I learned something)

- kapakay a anseran akn mapita so module ka naba pun deadline (I can answer the module anytime because there is no deadline)

- $\quad$ pkaswa iyan na mala oras pki anseron (I can answer at any time)

- mababaya ako milay sa storya labaw ron so manga bago a tuladan. (I am amused or excited by the stories and the pictures here are colorful)

- and pukasuwaa akn ron (I learned something)

- madakel oras akn ron kapakay a amay akn dun pasaden (I have plenty of time I can put off answering first)

- miyakatipid ako sa mga gamit sa school. (I saved on school supplies)

\section{Theme}

Self-Studying

(2)

Individual Learning Pace

- adun a miyasuwa akun ron pero mas

More time to Reflect mapiya dun so face to face. (I learned something but face-to-face is different)

- adun a oras akn ko ped a leson (I still have time to complete the remaining worksheets)

- adun oras akn a pag focus ko galbek akn. (I spend a lot of time on other activities)

Table 3.1 shows the Learners' Perceived Effect of Modular Approach to the Reading Proficiency of the Learners. The result of analysis found that most of learners was bored in module. Another thing that learners has an Individual Learning Pace. It implies that the respondents self-pacing that more or less stands alone as the individualized component of this instructional system.

According to Nardo (2017), the use of modules encourages independent study. One of the benefits of using modules for instruction is the acquisition of better self-study or learning skills among students. Students engage themselves in learning the concepts presented in the module. They develop a sense of responsibility in accomplishing the tasks provided in the module. With little or no assistance from others, the learners progress on their own. They are learning how to learn; they are empowered. 
Table 3.2: Parents' Perceived Effect of Modular Learning Approach to the Reading Proficiency of the Learners

\section{Questions}

1. How do you find Modular Approach and why?
Responses
ka matas kon so lesson ago so panganseran. (The lesson and activities to be answered are long)
- miyakatastas so paganseran. (The length of the answer)
- di pamakeneg so wata akn. (My child is not listening to me)
- mas mapiya so face to face. Mida dun so teacher ago sekta a lokes. (Still nice face to face. (The teacher and us parent are really different)
- maregen so manga ped a subject mas labaw ron so antonai suwaan ron. (Other subjects are difficult especially the instruction )
- $\quad$ Mida so adun a suwa iyan sa da suwa iyan. (People who have learned are different from those who have not learned)
- $\quad$ di pamakineg so wata ta se rekta (My child is not listening to me)
- $\quad$ kasi ako ang naging teacher at kurang so oras lagid aya and galbek ka (I'm stressed and I don't have enough time, especially since I have an office)

\section{Theme}

\section{Boring}

Difficult

Stressful

.

Table 3.2: Parents' Perceived Effect of Modular Approach to the Reading Proficiency of the Learners (cont'n.)

\section{Questions \\ Responses \\ Theme}

2. Do you think it beneficial

Pukaunungan ta so wata ta, di ta

Quality Time to you? Yes or No? Why? maalek o anda miyasong. (My child si vigilant, I am confident because he is safe)

- mapasad so module na and oras ta ko wata ta. (After module greater time with children) 
- miyada sa bayadan so wata akn a Cost Saving

mapasang kapamasa sa gitagitaan

oman kami maleng. (I lost the cost of buying a toy outside the school gate every time my son and ( go home)

- miyada sa gastos so bayad sa motor gira psung sa eskwelaan. (The budget lost the tricycle fare free)

- di ako maalek o kadasangan so wata ta gira ptarapas sa lalan. (I will no longer worry about my child passing or crossing the road)

- di ta maalek o anda pakasong so wata ta ka sasaya siran bo sa walay (I'm not scared anymore because I know my son is just at home)

Table 3.2 shows Parents' Perceived Effect of Modular Learning Approach to the Reading Proficiency of the Learners. The result of analysis found in this table was parents find it difficult because working from home will now have additional work like providing tech support or guidance in their schoolwork. It implies that parents learned how to manage their day and to make the best of learning at home in the most challenging of circumstances. This will require a learn-as-you-go approach, adapting to their child's specific needs, and working with them as co-stakeholders in their success.

According to Selwyn (2011), some parents feel more connected to their child's schoolwork while others see this as an additional burden.

Table 3.3: Summary of the Learners and Parents' Perceived the Effect of Modular Approach to Reading Proficiency of The Learners $(n=64)$

\begin{tabular}{|c|c|c|c|c|}
\hline \multirow{4}{*}{$\begin{array}{l}\text { How do you finc } \\
\text { Approach and why? } \\
\text { (Experience) }\end{array}$} & Learners & Boring & 26 & 40.6 \\
\hline & & Difficult & 10 & 15.6 \\
\hline & & Difficult & 20 & 30.8 \\
\hline & & Stressful & 22 & 33.8 \\
\hline \multirow{3}{*}{\multicolumn{2}{|c|}{$\begin{array}{l}\text { Do you think it bel } \\
\text { Yes or No? Why? } \\
\text { (Benefits) }\end{array}$}} & Quality Time & 17 & 26.2 \\
\hline & & Keeping children safe & 30 & 46.2 \\
\hline & & Cost Savings & 18 & 27.7 \\
\hline
\end{tabular}


Table 3.3 shows Summary of the Learners and Parents' Perceived the Effect of Modular Learning Approach to Reading Proficiency of The Learners $(n=64)$. It shows that learners had a difficulty experience in modular approach with a percentage result of $15.6 \%$. The results also shows that the beneficial of modular approach has the lowest percentage of $15.6 \%$ which is the learners more time to reflect on modular approach. It simply implies that respondents have a difficult to comprehend modular approach.

According to Gonzales (2015), to surpass the difficulties faced by the students in the traditional classroom situation, modular approach may be a good alternative since it is student-centered, self-paced, and requires no note-taking.

\section{Problem 4: Do the learners and parents perceived effect of Modular Approach related to their profile?}

Table 4.1: Relationship Between the Learners' Profile and Perceived Effect of Modular Approach and Their Profile

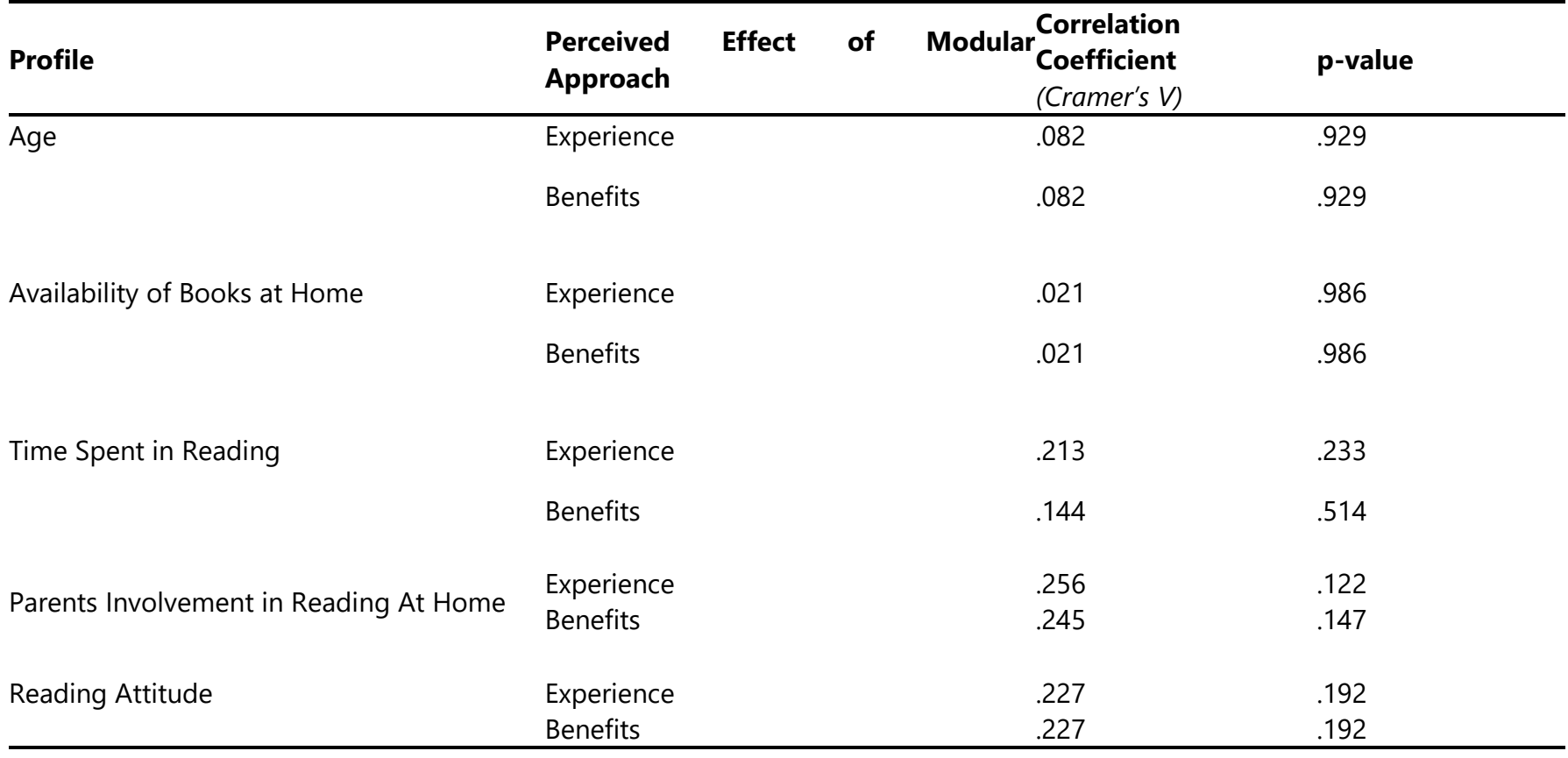

Table 4.1 shows Relationship between the Learners' Profile and Perceived Effect of Modular Approach and Their Profile. The results showed that the learners' perceptions are not significantly related to their profile. It implies that bigger correlation coefficient such as .2 and above somehow showed a wake relationship but not significant.

According to Tarusan and Verdan (2013), parental involvement may be of help, aside from building active networks in the community.

Table 4.2: Relationship Between the Parents' Profile and Perceived Effect of Modular Approach and Their Profile

\begin{tabular}{|c|c|c|c|c|}
\hline Profile & $\begin{array}{l}\text { Perceived } \\
\text { Approach }\end{array}$ & Effect of & $\begin{array}{r}\text { Modular } \begin{array}{c}\text { Correlation } \\
\text { Coefficient } \\
(\text { Cramer's V) }\end{array} \\
\end{array}$ & p-value \\
\hline \multirow[t]{2}{*}{ Highest Educational Attainment } & Experience & & .155 & .535 \\
\hline & Benefits & & .121 & .754 \\
\hline \multirow[t]{2}{*}{ Time Spent in Coaching Reading } & Experience & & .211 & .216 \\
\hline & Benefits & & .166 & .468 \\
\hline \multirow[t]{2}{*}{ Learners Involvement in Reading At Home } & Experience & & .241 & .152 \\
\hline & Benefits & & .192 & .300 \\
\hline
\end{tabular}


Table 4.2 shows Relationship between the Parents' Profile and Perceived Effect of Modular Approach and Their Profile. The results showed that the parents' perceptions are not significantly related to their profile. It implies that bigger correlation coefficient such as .2 and above somehow showed a wake relationship but not significant.

According to Sapungan, and Sapunga (2014), if we involve the parents in educating their children, it is tantamount to saying that the school is proactive in implementing changes or development among the students. As parent's involvement is increased, teachers and school administrators also raise the chance to realize quality reform in education.

\section{Problem 5: What is the learners' level of reading proficiency?}

Table 5: Learners' Level of Reading Proficiency

\begin{tabular}{|c|c|c|c|c|}
\hline $\begin{array}{l}\text { Comprehension } \\
\text { Score (\%) }\end{array}$ & Frequency & $\%$ & Mean & Oral Reading Level \\
\hline $80-100$ & 23 & 35.9 & 85.2 & Independent \\
\hline $59-79$ & 26 & 40.6 & 67.0 & Instructional \\
\hline Total & 64 & 100.0 & 67.5 & Instructional \\
\hline
\end{tabular}

Table 5 shows the Learners' Level of Reading Proficiency. The results shows that the lowest oral reading level of the learners' comprehension score with a percentage of 23.4. It implies that the oral reading level of the learners was in frustration level.

According to Spear- Swerling (2015), we can use the simple view of reading to identify the child's profile of reading difficulty. From there, we should conduct more fine-grained assessments to determine the child's specific skills and how to target instruction. At each grade level, certain types of difficulties will likely be common, which means that children can be grouped together for differentiation of instruction in small, flexible groups. For example, in a typical third-grade class, difficulties with word-recognition and decoding would often involve decoding two-syllable or multisyllabic words, and children with these needs could be grouped together.

\section{Problem 6: Do the perceived effectiveness of Modular Learning Approach to the learners' reading proficiency related to} the learners' actual reading proficiency?

Table 6.1: Relationship Between the Learners' Perceived Effect of Modular Learning Approach and Their Actual Oral Reading Proficiency

\begin{tabular}{|c|c|c|c|c|c|}
\hline $\begin{array}{l}\text { Perceived } \\
\text { Approach }\end{array}$ & Effect of & Modular & Learning ${ }_{\text {Oral Reading Proficiency }}$ & $\begin{array}{l}\text { Correlation } \\
\text { Coefficient } \\
\text { (Cramer's V) }\end{array}$ & p-value \\
\hline Experience & & & Oral Reading Level & .201 & .268 \\
\hline Benefits & & & Oral Reading Level & .201 & .268 \\
\hline
\end{tabular}

Table 6.1 shows the Relationship between the Learners' Perceived Effect of Modular Learning Approach and Their Actual Oral Reading Proficiency. The results shows that there is no significant influence as the $p$-value has the same level significant of .268. This means that the modular approach does not affect the respondents' reading attitude and proficiency.

According Naboya (2019), showed that academic emotions are significantly related to students' motivation, learning strategies, cognitive resources, self-regulation, and academic achievement as well as to personality and classroom antecedent. 
Table 6.2 Relationship Between the Parents' Perceived Effect of Modular Approach and Their Learners 'Actual Oral Reading Proficiency

\begin{tabular}{llll}
\hline Perceived Effect of Modular Approach & Oral Reading Proficiency & $\begin{array}{l}\text { Correlation } \\
\text { Coefficient } \\
\text { (Cramer's V) }\end{array}$ & p-value \\
\hline Experience & Oral Reading Level & .174 & .425 \\
Benefits & Oral Reading Level & .175 & .419
\end{tabular}

Table 6.2 Relationship between the Parents' Perceived Effect of Modular Approach and Their Learners 'Actual Oral Reading Proficiency. Table 6.2 shows the Relationship between the Parents' Perceived Effect of Modular Learning Approach and Learner's Actual Oral Reading Proficiency. The results shows that the highest p-value was .425 in experience. This means that the modular approach affects the respondents' reading attitude and proficiency.

According to Martinez (2017), speaking proficiency is an important skill that helps one to be successful, and the development of speaking proficiency has been the focus of language classrooms. However, students' level of proficiency has been noticeably varied even though they had similar learning experiences.

Problem 7: How do learners' actual reading proficiency significantly differed when analyzed according to the learner's profile and parents' profile?

Table 7.1: Results of The Analyses on the Differences in the Learners' Oral Reading Proficiency When Grouped According To Their Profile

\begin{tabular}{|c|c|c|c|c|c|}
\hline \multirow[t]{2}{*}{ Profile } & & \multicolumn{2}{|c|}{$\begin{array}{l}\text { Oral } \\
\text { Proficiency }\end{array}$} & \multirow[t]{2}{*}{$\begin{array}{l}\text { Test } \\
\text { Value }\end{array}$} & \multirow[t]{2}{*}{ Statisticp-value } \\
\hline & & Mean & QI & & \\
\hline \multirow[t]{2}{*}{ Age } & 9 years old & 60.9 & 1 & 3.404 & .182 \\
\hline & 10 years old & 71.0 & I & & \\
\hline \multirow[t]{2}{*}{ Availability of Books at Home } & None & 62.6 & I & 233.5 & .155 \\
\hline & Available & 68.6 & I & & \\
\hline Time Spent in Reading & A lot & 71.1 & I & & \\
\hline \multicolumn{2}{|c|}{ Parents Involvement in ReadingReading at Home with Parents } & 68.0 & I & 3.618 & .168 \\
\hline \multirow[t]{2}{*}{ At Home } & Talk About the Meaning of Story & 66.7 & I & & \\
\hline & Ask What is Happening in the Story & 67.5 & l & & \\
\hline \multirow[t]{2}{*}{ Reading Attitude } & Very Positive & 69.2 & I & 125.2 & $.032^{*}$ \\
\hline & Positive & 65.6 & 1 & & \\
\hline
\end{tabular}

Qualitative Interpretation (QI): I - Instructional

*Significant at 0.05 level 
Table 7.1 shows the Results of The Analyses on the Differences in the Learners' Oral Reading Proficiency When Grouped According To Their Profile. The result show that 10 years old learners has a higher oral reading proficiency mean compared to other age brackets. It shows also that there is an availability of books at home which has a mean score of 68.8. It shows that the highest mean in parents' involvement at home has 68.0. The table also shows that the highest mean in reading attitude has 69.2. The result is shown above that there is significant differences in the learners' oral reading proficiency when grouped according to their profile, since the $p$-value is 0.005 is highly significant at the level 0.01 leading to the rejection of the null hypothesis. . Base on the results, this could only mean that the modular approach affects their reading attitude and proficiency.

It implies that the previous assessment or evaluation test to the learning process was not measure through reading comprehension and reading attitude survey, since it is depicted on the result that there is a significant influence of modular approach of the learners to their reading attitude and proficiency.

According to Malik (2012) also contend that the teaching approach in modularized program should allow students to proceed at their own pace, give opportunity to choose their own learning style, and allow them to identify their strengths and weaknesses. Moreover, it should consider individual difference by providing flexibility with respect to the pacing, format, and contents of the instruction Hernandez (2012).

Table 7.2: Results of The Analyses on the Differences in the Learners' Oral Reading Proficiency When Grouped According To The Parents' Profile

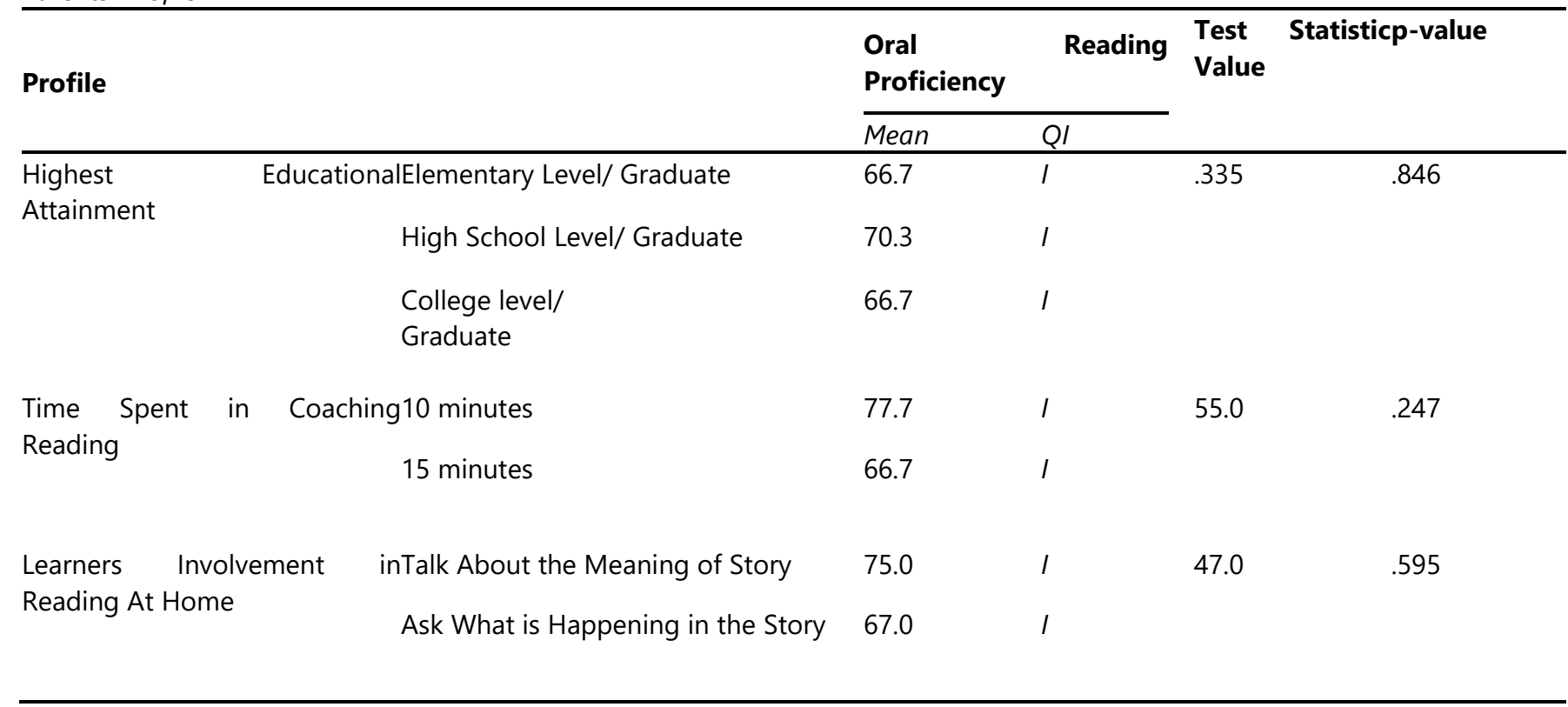

Qualitative Interpretation (QI): I - Instructional

*Significant at 0.05 level

Table 7.2 shows the Results of the Analyses on the Differences in the Learners' Oral Reading Proficiency When Grouped according To the Parents' Profile. The result shows that high school level is the highest mean of highest educational attainment of the respondents' parents has 70.3. It shows also that the highest mean in time spent in reading was 77.7. The table also shows the learners involvement in reading at home which is the 'talk about the meaning of story' has a mean of 75.0. The result is shown above that there is significant differences in the learners' oral reading proficiency when grouped according to the parents' profile, since the p-value is 0.05 is highly significant at the level 0.01 leading to the rejection of the null hypothesis. Base on the results, this could only mean that the modular approach affects their reading attitude and proficiency.

According to Seale (2020), Parents are the experts on their children. Whereas teachers change annually, parents accumulate a wealth of knowledge about their children as learners. Moreover, they are uniquely positioned to read with their kids in a one-onone setting. There is no smaller classroom than a family's living room, and there is no better way to personalize instruction than through a parent. 
Problem 8: What enhanced English reading module maybe drawn from the findings of the study?

\section{Grade 3 Enhanced Reading Module (2 ${ }^{\text {nd }}$ Quarter)}

I. Rationale

Reading is defined as a cognitive process that involves decoding symbols to arrive at meaning. Reading is an active process of constructing meanings of words. Reading with a purpose helps the reader to direct information towards a goal and focuses their attention. Although the reasons for reading may vary, the primary purpose of reading is to understand the text. The essence of reading is that it allows for a greater perspective on the world and on others. Reading can take us outside of our closed-off bubble, allowing us to see a different view on the world, one outside of our own. Reading is a chance to live through the lives of others without stepping outside of our comfort zone or even traveling anywhere else. It's a chance to live another life without even leaving your home. It will transport our imagination to places we've never been before, and perhaps never even knew existed.

Based on the findings of this study, it is important and necessary for the child to develop the love of reading. That this reading module is presented. An enhance reading module to develop to have the following objectives:

II. General Objectives

1. To have a positive attitude towards reading.

2. To enhance the grammar skills.

3. To develop critical thinking skills.

III. Reading selection

A. Read the short story carefully. Answer the following questions.

\section{"Precious Hen"}

Four-year old Alfie could hardly carry the big bag given to him as a birthday gift that day. Something was moving inside.

"Help me, Mother. Help me open the bag, please," Alfie said.

"Your gift will run away if you're aren't careful," his uncle Wowie, the giver of the gift, said.

"It's a big red hen! It's mine!" Alfie exclaimed as he cuddled it.

With the help of his grandmother, the hen was placed in a wide chicken basket.

The first thing Alfie did in the morning was to see the hen; feed it and play with it. It was the same last thing he would see before going to bed.

One Friday morning, Alfie and his father went to Masjid for Juma'ah prayer. It was almost 1:00 o'clock in the afternoon when they arrived home. As soon as they reached home, Alfie ran to see his red hen.

"Mother, my hen is not here! It's gone! Please help me find it!" Alfie cried.

"Come, Alfie. Let's eat our lunch first," his grandmother said.

At the table, Alfie saw that their food is fried chicken.

"This is my hen, isn't it, Grandmother?"

"I'll buy you another one tomorrow," said his grandmother. "You better eat now."

The following day Alfie's grandmother bought two hens in exchange for his red hen.

"No hen can take the place of my red hen," Alfie said sadly even as he played with his new hens.

1. Who is the main character of the story?

2. What time the families arrive at home?

3. Why Alfie cried?

4. Where do Alfie go when praying Jumma?

5. How did the grandmother exchange the red hen? 
B. Read the short story carefully. Answer the following questions and circle all the action words.

\section{Bad Hair Day}

On a small street you see a house with a sign that says, "Magic Hair Here."

You walk in and see a lady with a magic wand.

"Come in," she says. "Grab a chair. In less than a minute, you'll have magic hair!"

You sit. The lady looks at you, and says, "Clean bean, clean bean, turn this hair green!"

She taps your head and your hair grows long. She taps your head again and your hair turns green! Then she taps your head once more and your hair turns into green beans!

You love your new hair. You can cut off bits to eat. Then it grows back. You

never have a bad hair day again.

1. What is the title of the story?

2. Who has a magic wand?

3. Where the story happened?

4. Why the lady taps the hair?

5. How the story end?

C. Read the short story below and circle the letter of your correct answer.

\section{The Giant Panda}

The giant panda is the rarest member of the bear family. It is one of the world's most threatened animals.

The giant panda is very well loved. It is a special animal for the World Wildlife Fund. It has been their logo since the WWF was started in 1961.

Giant pandas live in forests in the mountain areas in central and southwest China.

As more roads and railway lines are built, the forest habitat is disturbed. When that happens, the pandas can't find enough bamboo to eat. And they need a lot to eat - almost 28 pounds of bamboo per day!

Through the efforts of the WWF and other groups, the number of giant pandas is on the rise. But it hasn't been enough to remove it from the endangered animal list.

1. Where do giant pandas live?

a.in northern Australia

b.in northwest India

c.in southwest China

2. What is the giant panda's habitat?

a. jungles

b. mountain forests

c. China

3.The giant panda is a member of the ape family.

a.True

b.False

c.It doesn't say in the story

4. How much bamboo does a giant panda eat in a day?

a.12 pounds

b.more than 25 pounds

c.It doesn't say in the story

5.What does "endangered" mean?

a.a danger to other animals

b .a danger to humans

c. threatened or in danger of dying out 
C. Read each passage. Answer the following questions.

1. Today was the last day of school before sem-break. The pupils in Miss Jane's class were very excited. Miss Jane was trying to teach a Math lesson but her pupils were not paying attention. Pupils were drawing on their papers and talking to each other. Miss Jane gave warnings but eventually they lost 10 minutes of their recess.

What caused the class to lose recess time?

2. The last show was finally over. The students at Angels Academy had worked so hard on their spring play. They had done three shows and each one had gotten great reviews. Putting on the play had been a lot of work. They had to practice every week. Find costumes and paint the props. But in the end it was worth it! The entire auditorium was filled with cheers and applause.

What caused the audience to cheer?

E. Practice. A parent or tutor should read along with the student, helping as needed. Answer the following questions.

Cause and effect are about how one thing can cause something else to happen. The cause is why something happened. The effect is what happened.

Here is a story about why birds build their nests differently. Think about cause and effect as you read.

The Magpie's Nest Of all the birds in the air, the magpie builds the very best nest. Long ago, all the birds came to Magpie and asked her to teach them how to build nests. So Magpie got them all together and began to show them how to do it. First, she took some mud and patted it into the shape of a pancake. "Ah ha!" said Thrush, and away she flew. So Thrush still builds her nest out of mud. Then Magpie arranged some twigs around in the mud. "Well of course," said Owl, and away she flew. Owls have never made better nests than that. Magpie turned the edges of the pancake up into a bowl shape, and put more twigs around the outside. "What a good idea!" said Sparrow, and Sparrow makes messy nests to this day. And so it went on. Each bird took away some knowledge of how to build nests, but none of them waited to the end. Finally, only silly Turtle-dove was left, and she hadn't been paying any attention all along. She had just been sitting there saying her silly cry. "Take two, take two-o-o-o. Take two, take two-o-o." Magpie was adding the last twig to her lovely nest. "Take two, take two-o-o" cried Turtle-dove. Magpie looked at Turtle-dove. "One's enough," she said. But the Turtle-dove kept on saying, "Take two, take two-o-o." Then Magpie got angry. "One's enough, I tell you." Still Turtle-dove repeated, "Take two, take two-o-o. Take two, take two-o-o." At last, Magpie got even angrier. No one but silly Turtle-dove was left to see her lovely nest that she had worked so long to build. She flew away to find some worms, and refused to show the birds how to build a nest again. And that is why different birds build their nests differently.

In this story, what is the effect of each cause? Write your answer.

1. Magpie makes the very best nest. What happened because Magpie makes the very best nest?

2. Thrush watched Magpie pat some mud into a pancake shape, and flew away. What happened because Thrush flew away after watching Magpie shape the mud?

\section{Summary, Conclusion and Recommendation}

This chapter presents the summary of the findings, recommendations, and conclusions drawn from the analyzed data. Some recommendations are presented which can be utilized by future researchers.

\subsection{Summary}

This study aimed to determine the effects of modular approach to the reading attitude and proficiency of students in the new normal in Mindanao State University Integrated Laboratory School for the school year 2020-2021. The respondents involved in this study are the grade 3 students of Mindanao State University Integrated Laboratory School which comprises of two sections. First, is the grade 3 Virgo has a population of thirty while Sagittarius has a population of thirty four, and a sixty four total population of both sections. A standardized instrument was utilized in gathering data for this study. A survey was additionally used which is separated into three parts. Part one is composed of Reading Proficiency- PHIL IRI. Part two is the learner's profile in terms of age, time spent in reading, and reading attitude. Part three is the structured questionnaire for the effect of modular learning approach to reading proficiency.

The present study was conducted based on the primary concern regarding the use of modular approach that affect their reading attitude and proficiency. Hence, the purpose of this study were: (a) to analyze the learners profile in terms of age, time spent in 
reading, reading attitude, (b) to determine the perceived effect of modular learning approach to reading attitude and proficiency of the respondents, (c) to analyze the parents' profile in terms of time spent in coaching learner in reading, highest educational attainment, (d) to determine the level of reading attitude and proficiency of the learners. In this regard, the following salient findings surfaced.

\subsection{Summary of Findings}

1. Based on the frequency and percentage distribution of the learner-respondents profile the majority of the respondents were 10 years old. In terms of availability of books at home, there were 81.3 percent available books. In terms of time spent in reading, there were 76.6 percent who spent time in reading. There were 76.6 percent in reading at home with parents. Majority of these respondents was at the right age suited for grade 3.

2. Reveals that majority parent- respondents are college level/graduate.

3. In terms of the learners and parents perceived effect of modular learning approach to reading proficiency of the learners, majority of the learners were bored. Second, most of the respondent's parents find module difficult. Third, the results also shows that the beneficial of modular approach has the lowest percentage of $15.6 \%$.

4. The results showed that the learners' perceptions are not significantly related to their profile. The results showed also that the parents' perceptions are not significantly related to their profile.

5. Learners' level of reading proficiency, it shows that the lowest oral reading level of the learners' comprehension score with a percentage of 23.4 .

6. As to the relationship between the learners' perceived effect of modular learning approach and their actual oral reading proficiency, it shows that there is no significant influence as the $p$-value has the same level significant of .268. Second, it shows that the highest $p$-value was .425 in experience

7. As to the relationship between the parents' perceived effect of modular approach and their learners 'actual oral reading proficiency, it shows that there is significant differences in the learners' oral reading proficiency when grouped according to their profile.

8. It shows that this enhanced English reading module was needed to adjusted plans to make a consecutive plan that arrives at each different student.

\subsection{Conclusion}

This study investigated the effect of modular approach on the reading attitude and proficiency of the learners and was able to identify the variables affecting reading attitude and proficiency of grade 3 students of Mindanao State University- Integrated Laboratory School. Results revealed that the modular approach effects the reading attitude and reading proficiency of the learners. Further, it can be concluded that modular approach can still be enhanced since the findings of analyses showed that they have fair level of reading attitude and proficiency. In other words, there is still a chance for them to develop reading attitude and proficiency. And because the result is focused only with the constructivism by John Dewey, their reading attitude and proficiency can be enhanced through the help of teacher and the involvement of the parents in modular approach.

\subsection{Recommendation}

Based on the findings of the study, the following are hereby recommended.

School Administrators. This study provides them solutions that allow for the safe return of students in coming months, modular design and construction presents great opportunities for both short- and long-term considerations.

Faculty Members. The result of this study presents relevant insights which provides them additional knowledge to enhance the English reading module and consider on how they can help every student accomplish the goals of the course.

Parents. The results of the study presents applicable insights which provides them time, appropriate praises, encouragement, and rewards to heighten their child's motivation to learn.

Future Researchers. This study serves as stimulant in identifying other variables to be used in research to further enhance English reading module. 


\section{References}

[1] An, S. (2013). Schema Theory in Reading. Changchun University of Science \& Technology, Changchun, China: Academy Publisher Manufactured in Finland.

[2] Byro, Crisalinda C., "A study of the relationship between reading attitude and gender in fourth grade children" (2000). Theses and Dissertations. 1640.https://rdw.rowan.edu/etd/1640

[3] Cabrera, A. F., Peralta, A. M., \& Kurban, E. R. (2018). The invisible 1\%: A comparison of attaining stepping stones toward college between military and civilian children. Journal of Higher Education, 89(2), 208-235. https://doi.org/10.1080/00221546.2017.1368816

[4] Cadeliña, S. (2013). Attitude towards Learning the English Language and the Reading Comprehension of the Second Year Engineering Students of the University of the Immaculate Conception. ARETE, 1(1). Retrieved from http://ejournals.ph/form/cite.php?id=5660

[5] Calderón, C. (2004), "The Output Cost of Latin America's Infrastructure Gap." In W. Easterly and L. Servén, eds., the Limits of Stabilization: Infrastructure, Public Deficits, and Growth in Latin America. Palo Alto: Stanford University Press and the World Bank.

[6] Cantor, P., Osher, D., Berg, J., Steyer, L., \& Rose, T. (2018). Malleability, plasticity, and individuality: How children learn and develop in context. Applied Developmental Science, 1. doi:10.1080/10888691.2017.1398649 [Taylor \& Francis Online], [Web of Science ${ }^{\circledR}$ ], [Google Scholar]

[7] Carrell, P.L. and Eisterhold, J.C. (1983) "Schema Theory and ESL Reading Pedagogy", in Carrell, P.L., Devine, J. and Eskey, D.E. (eds) (1988) Interactive Approaches to Second Language Reading. Cambridge: CUP.

[8] Carter, M. (2012). The effects of reading acceleration on reading comprehension and decoding accuracy in high school students with reading high school students (Order No. 3550206). Available from ProQuest Dissertations \& Theses Global. (1285215384). Retrieved from https://search.proquest.com/docview/1285215384?accountid=139409

[9] Caravolas, M., Lervåg, A., Mousikou, P., Efrim, C., Litavský, M., Onochie-Quintanilla, E., et al. (2012). Common patterns of prediction of literacy development in different alphabetic orthographies. Psychological Science, 23, 678-686.

[10] Cheadle, J. E., \& Amato, P. R. (2011). A quantitative assessment of Lareau's qualitative conclusions about class, race, and parenting. Journal of Family Issues, 32(5), 679-706. https://doi.org/10.1177/0192513X10386305

[11] Cruz-Deveza, L. (2016). Reading habit as a factor of writing proficiency in English. Xavier University, Ateneo de Cagayan, Cagayan de Oro city.

[12] Gonzales, E. E. (2015). A Modular Approach Utilizing Decision Tree in Teaching Integration Techniques in Calculus, Department of Arts, Sciences and Teacher Education, City College of Calamba, Calamba City, Laguna, Philippines.

[13] Hernandez, R. (2012). Does continuous assessment in higher education support student learning? Higher Education, 64, 489502. [Crossref], [Web of Science ${ }^{\circledR}$ ], [Google Scholar]

[14] Ibyatova, L., Oparina, K., \& Rakova, E. (2018, May). Modular approach to teaching and learning English grammar in technical universities. In SOCIETY. INTEGRATION. EDUCATION. Proceedings of the International Scientific Conference (Vol. 1, pp. 139-148).

[15] Jamal, A. (2016). Vocabulary Learning Theories- a keen perspective. Global Journal for research analysis. Vol. 5, No. 12.

[16] Johnson, M.J., Kress, R.A., \& Pikulski, P. L. (1987). INFORMAL READING INVENTORIES (2ND Ed.). Newark, DE: International Reading Association.

[17] Jones, R. A. (2017). English language learners' lexical inferencing and vocabulary development (Order No. 10262354). Available from ProQuest Dissertations \& Theses Global. (1888830720). Retrieved from https://search.proquest.com/docview/1888830720?accountid=139409

[18] Kalandayag, S. (2014). Reading performance of grade six pupils in sultan Kudarat-I district, Maguindanao II division. Cotabato city State Polytecgnic College. Cotabato City.

[19] Kennedy E. \& Shiel, G. (2012). Raising literacy levels with collaborative on-site professional development in an urban disadvantaged school. The Reading Teacher, 63(5), Special Themed Issue on Urban Education. Delaware, U.S.A.: International Reading Association.

[20] Korat, Ofra \& Tal,. (2010). How New Technology Influences Parent-child Interaction: The Case of e-book Reading. First Language. 30. 139154. $10.1177 / 0142723709359242$.

[21] Lave, J., and Wenger, E., (1991). Situated Learning. Legitimate peripheral participation, Cambridge: University of Cambridge Press

[22] Lee, J., Schallert, D. L. (2014). Literate actions, reading attitudes, and reading achievement: Interconnections across languages for adolescent learners of English in Korea. The Modern Language Journal, 98, 553-573. doi:10.1111/modl.12088

[23] Lopukhova, Yulia \& Makeeva, Elena. (2017). Creating Virtual Learning Environment: Shared Online Learning in University Education. International Journal for Cross-Disciplinary Subjects in Education. 8. 10.20533/ijcdse.2042.6364.2017.0412.

[24] Malik, K. (2012). Effects of modular and traditional approaches on students' general comprehension. Elixir Social Studies, 42, 62286231. [Google Scholar]

[25] Martinez, D. A. (2017). Personality Types, Affective Filters and English Proficiencyof Grade Ten Students in Davao City. Tin-aw, 1(1). Retrieved from http://ejournals.ph/form/cite.php?id=13476

[26] Martínez, R. S., Aricak, O., \& Jewell, J. (2008). Influence of reading attitude on reading achievement: A test of the temporal-interaction model. Psychology in the Schools, 45(10), 1010-1023. Retrieved from Eric Database May 10, 2013 http://ezproxy.nwmissouri.edu:2068/Library/IPChecking.asp?http://ezproxy.nwmissouri.

[27] McKenna, M.C., \& Kear, D.J. (1990, May). Measuring attitude toward reading: A new tool for teachers. The Reading Teacher, 43(8), 626-639. http://dx.doi.org/10.1598/RT.43.8.3 Copyright @ International Reading Association. All rights reserved.

[28] McKenna, M.C., Conradi, K., Lawrence, C., Jang, B.G., \& Meyer, J.P. (2013).Reading attitudes of middle school students: Results of a U.S. survey. Reading Research Quarterly, 47, 283-306. doi:10.1002/RRQ.021

[29] Naboya, M. (2019). Effect of Modular Approach on the Level of Achievement of Students in Inorg Chemistry Journal of International Academic Research for Multidisciplinary 7 (1), 36-55

[30] Nardo, M. T. B. (2017). Modular Instruction Enhances Learner Autonomy. American Journal of Educational Research, 5(10), $1024-1034$. 
[31] Pedrosa, Bastianello, \& Hutz. (2014). Optimism scale: Evidence of psychometric validity in two countries and correlations with personality. Read https://daneshyari.com/en/article/7248453.

[32] Petcher, S. (2010). Assessing Adolescents' Motivation to Read. https://doi.org/10.1598/JAAL.50.5.5

[33] Perkins, D.N. (1991). What Constructivism Demands of the Learner. Educational.Technology, 31(9), 19-21. Retrieved June 17, 2021 from https://www.learntechlib.org/p/170793/

[34] Reardon, S., Valentino, R. and Shores, K. 2012."Patterns of Literacy among U.S. Students" in "Literacy Challenges for the Twenty-First Century," The Future of Children, Volume 22, Number 2, Fall 2012.

[35] Rogers, P. (2012). Introduction to Impact Evaluation. Impact Evaluation Notes No. 1. Washington DC: InterAction. - This guidance note outlines the basic principles and ideas of Impact Evaluation including when, why, how and by whom it should be done.

[36] Romeo, C. (2017). Oral reading skills of grade seven students. Xavier university- Ateneo de Cagayan, Cagayan de Oro city.

[37] Sapungan, G., \& Sapungan, R. (2014). Parental involvement in child's education: importance, barriers and benefits. Asian Journal of Management Sciences \& Education, 3(2).

[38] Seale, C. (2020)"Thinking Like a Lawyer: A Framework for Teaching Critical 1 Thinking to All Students,".

[39] Seitz, Lindsey. (2010). Student Attitudes toward Reading: A Case Study Shuying, A. (2013). Schema Theory in Reading. Theory and Practice in Language Studies. 3. 10.4304/tpls.3.1.130-134.

[40] Spady, W. (1998). Paradigm lost: Reclaiming America's educational future. Arlington, VA: American Association of School Administrators.

[41] Spear-Swerling, L. (2015). Common types of reading problems and how to help children who have them. The Reading Teacher, 69(5), 513522.

[42] Taga, B. (2011). The reading ability in English of the students of Bukidnon state University. Xavier University, Cagayan de Oro city.

[43] Tarusan, M. E. \& Verdan, N. M. (2013). Parental Involvement in the Education of Grade Six Pupils and their Reading Ability. IAMURE International Journal of Multidisciplinary Research, 6(1). Retrieved from http://ejournals.ph/form/cite.php?id=2568

[44] Tunde,A., (2014). Effect of Visual Illustrations of Difficult Words on Junior Secondary School Students' Performance in Reading Comprehension Tests inllorin, Nigeria. In Wale Adegbite and Billy Olajide (Eds.) English in the Nigerian Environment: Emerging Pattern and New Challenges. Unoh, S.O.(1983). Sense and Nonsense in Developmental Reading Programme. In Literacy andReading in Nigeria. RAN. 1, 145-156

[45] Voyer, D., \& Voyer, S.D. (2014). Gender differences in scholastic achievement: A meta-analysis. Psychological Bulletin, $140(4), 1174-1204$.

[46] Yunjung, Y. (2011). Factors in Vocabulary Acquisition through Reading. Purdue University 
APPENDIX A

LETTER TO THE ASSISTANT DEAN

ST MICHAEL'S COLLEGE

Iligan City

GRADUATE SCHOOL

Accredited: Philippine Accrediting Association of Schools and Universities (PAASCU)

March 2, 2021

Prof. Ebresamen W. Dipatuan

Assistant Dean, MSU- ILS

Marawi City

Dear Ma'am:

Assalamu alaikom Warahmatullahi Wabarakatuho!

The undersigned is conducting a research entitled "MODULAR APPROACH: ITS EFFECT ON LEARNERS' READING ATTITUDE AND PROFICIENCY IN THE NEW NORMAL" as a fulfillment of the requirements for the degree Master of Education Major in English Language Teaching.

In line with this, I would like to request permission from your good office that I be allowed to conduct or implement my research to the Grade 3 Section Sagittarius and Virgo in our school. I would like also to have you as an expert to guide me during the implementation of the research.

Rest assured that students' responses will be kept confidential and will be used for academic purpose only. Your approval of this request is highly appreciated.

Thank you and Wassalam!

Respectfully yours,

ASLIMA M. MAROHOMBSAR

Researcher
Noted by:

MELCHORA B. LECTOR, Ph.D.

Research Adviser

\section{APPENDIX B}

LETTER TO THE ELEMENTARY PRINCIPAL

\section{ST MICHAEL'S COLLEGE}

Iligan City

GRADUATE SCHOOL

Accredited: Philippine Accrediting Association of Schools and Universities (PAASCU)

March 2, 2021

Prof. Amira M. Abdulfattah

Elementary Principal, MSU-ILS

Marawi City

Dear Ma'am:

Assalamu alaikom Warahmatullahi Wabarakatuho!

The undersigned is conducting a research entitled "MODULAR APPROACH: ITS EFFECT ON LEARNERS' READING ATTITUDE AND PROFICIENCY IN THE NEW NORMAL" as a fulfillment of the requirements for the degree Master of Education Major in English Language Teaching. 
In line with this, I would like to request permission from your good office that I be allowed to conduct or implement my research to the Grade 3 Section Sagittarius and Virgo in our school. I would like also to have you as an expert to guide me during the implementation of the research.

Rest assured that students' responses will be kept confidential and will be used for academic purpose only. Your approval of this request is highly appreciated.

Thank you and Wassalam!

Respectfully yours,

ASLIMA M. MAROHOMBSAR

Researcher

Noted by:

\section{RITZCEN A. DURANGO, Ph. D.}

Dean, Graduate School

St. Michael's College

\section{APPENDIX C}

\section{LETTER TO THE PARENTS}

\section{ST MICHAEL'S COLLEGE}

Iligan City

GRADUATE SCHOOL

Accredited: Philippine Accrediting Association of Schools and Universities (PAASCU)

March 2, 2021

\section{To the Parents of Grade 3 Pupils}

Dear Ma'am/ Sir:

Assalamu alaikom Warahmatullahi Wabarakatuho!

The undersigned is conducting a research entitled "MODULAR APPROACH: ITS EFFECT ON LEARNERS' READING ATTITUDE AND PROFICIENCY IN THE NEW NORMAL" as a fulfillment of the requirements for the degree Master of Education Major in English Language Teaching.

In line with this, I would like to request permission from your good office that I be allowed to conduct or implement my research to the Grade 3 Section Sagittarius and Virgo in our school. I would like also to have you as an expert to guide me during the implementation of the research.

Rest assured that students' responses will be kept confidential and will be used for academic purpose only. Your approval of this request is highly appreciated.

Thank you and Wassalam

Respectfully yours,

ASLIMA M. MAROHOMBSAR

Researcher
Noted by:

MELCHORA B. LECTOR, Ph.D.

Research Adviser 


\section{APPENDIX D}

\section{QUESTIONNAIRES}

\section{ST MICHAEL'S COLLEGE}

Iligan City

\section{GRADUATE SCHOOL}

Accredited: Philippine Accrediting Association of Schools and Universities (PAASCU)

SUMMER FUN

"Let's have some fun this summer," says Leo.
"Let's swim in the river," says Lina.
"Let's get some star apples from the tree," says Leo.
"Let's pick flowers," says Lina.
"That is so much fun!" says Mama.
"But can you help me dust the shelves too?" "Yes, we can Mama," they say.
"Helping can be fun too!"

I. Read the short passage above and answer the questions below. Encircle the letter of the correct answer. Questions:

1.Who were talking to each other?
a. Lita and Lito
b. Lina and Lino
c. Lina and Leo

2. What were they talking about?

a. what to do during the summer

b. what to have during the summer

c. what to wear during the summer

3. The children in the story could be

a. brother and sister

b. neighbors

c. cousins

4. Which of these will they do if they are hungry?

a. pick flowers

b. pick guavas

c. go swimming

5. Doing something "fun" means

a. doing something in the summer

b. doing something in the house

c. doing something that we like

6. Which these is the best example of being helpful?

a. picking flowers

b. cleaning up

c. swimming

II. Elementary Reading Attitude Survey 


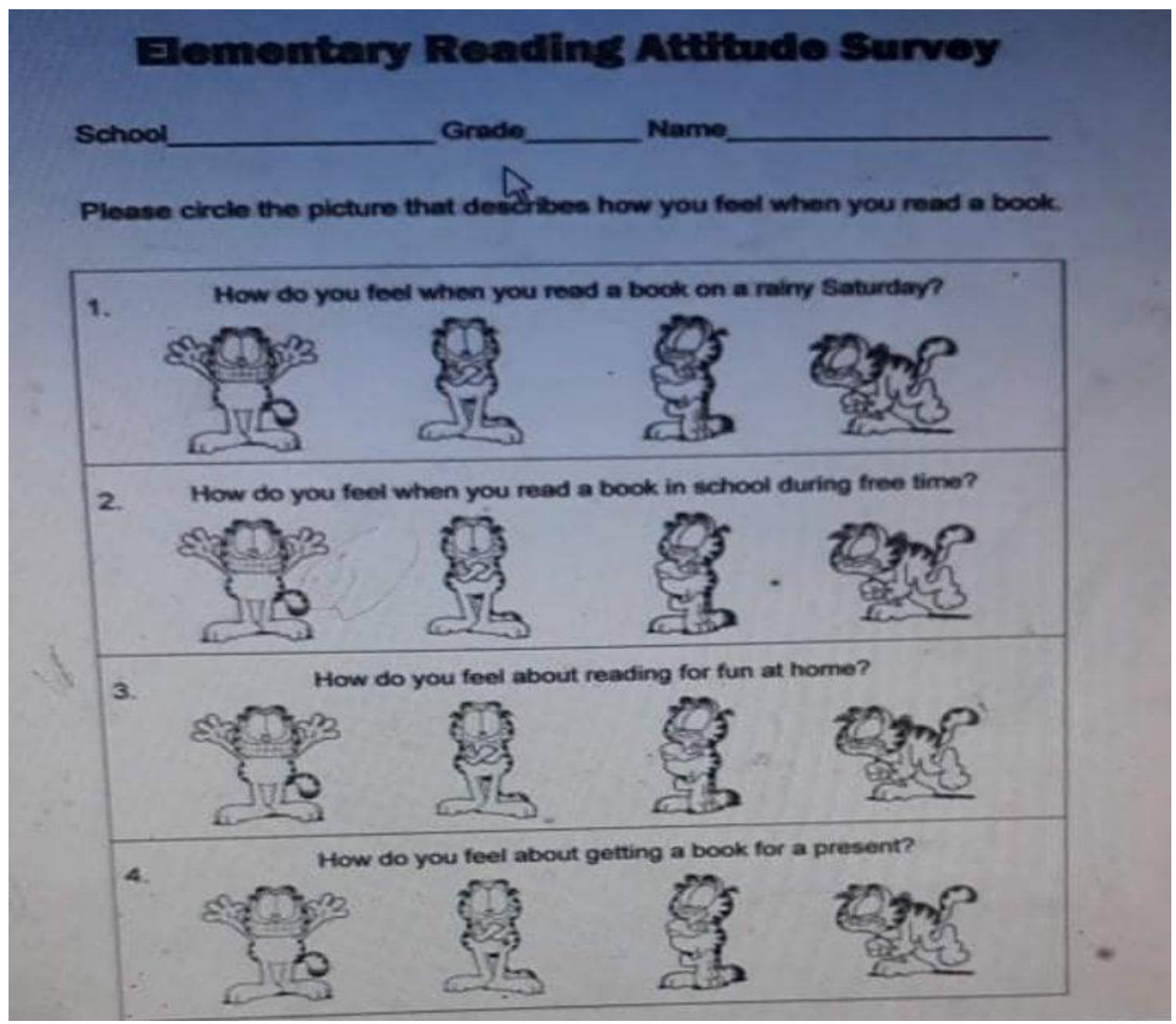




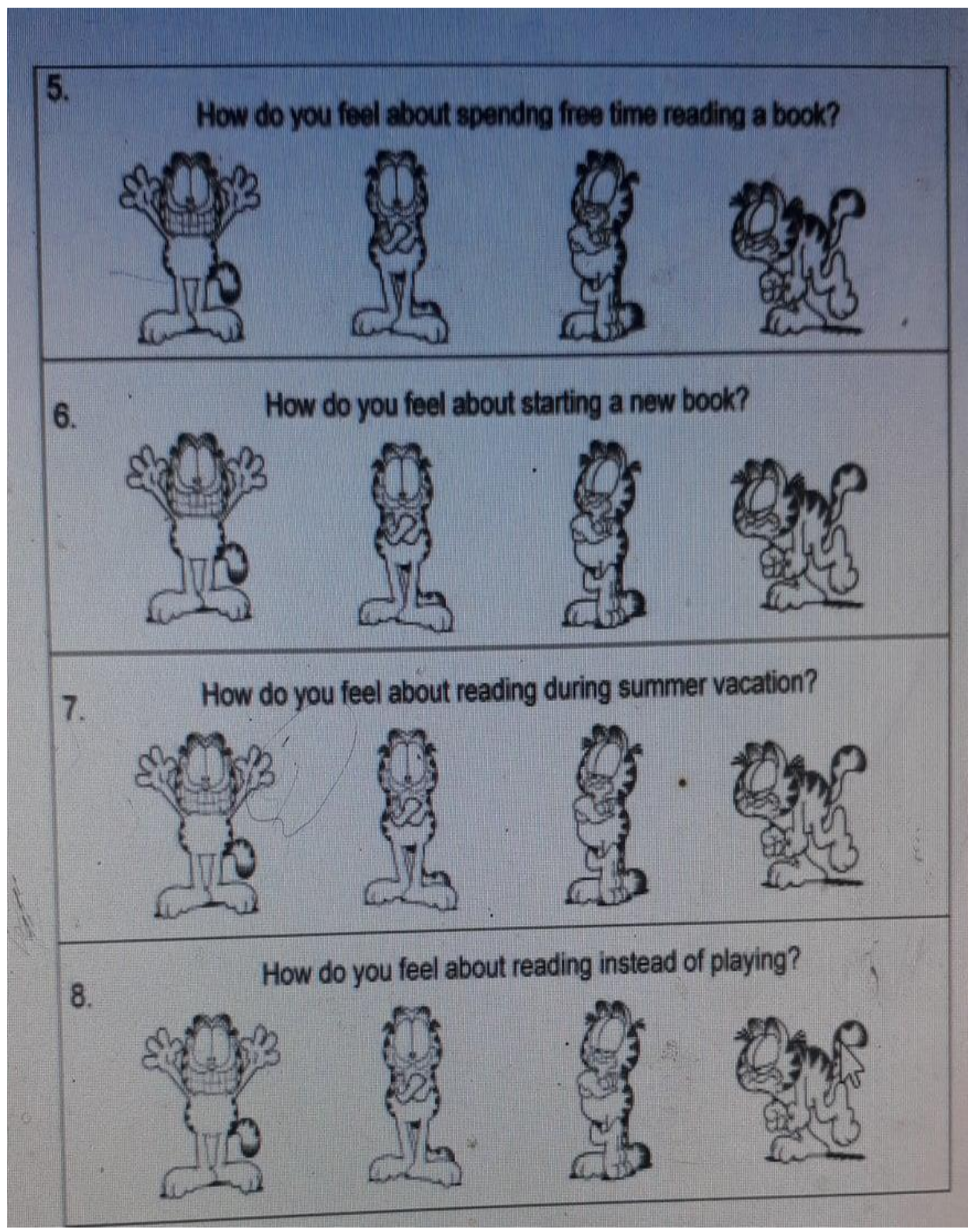



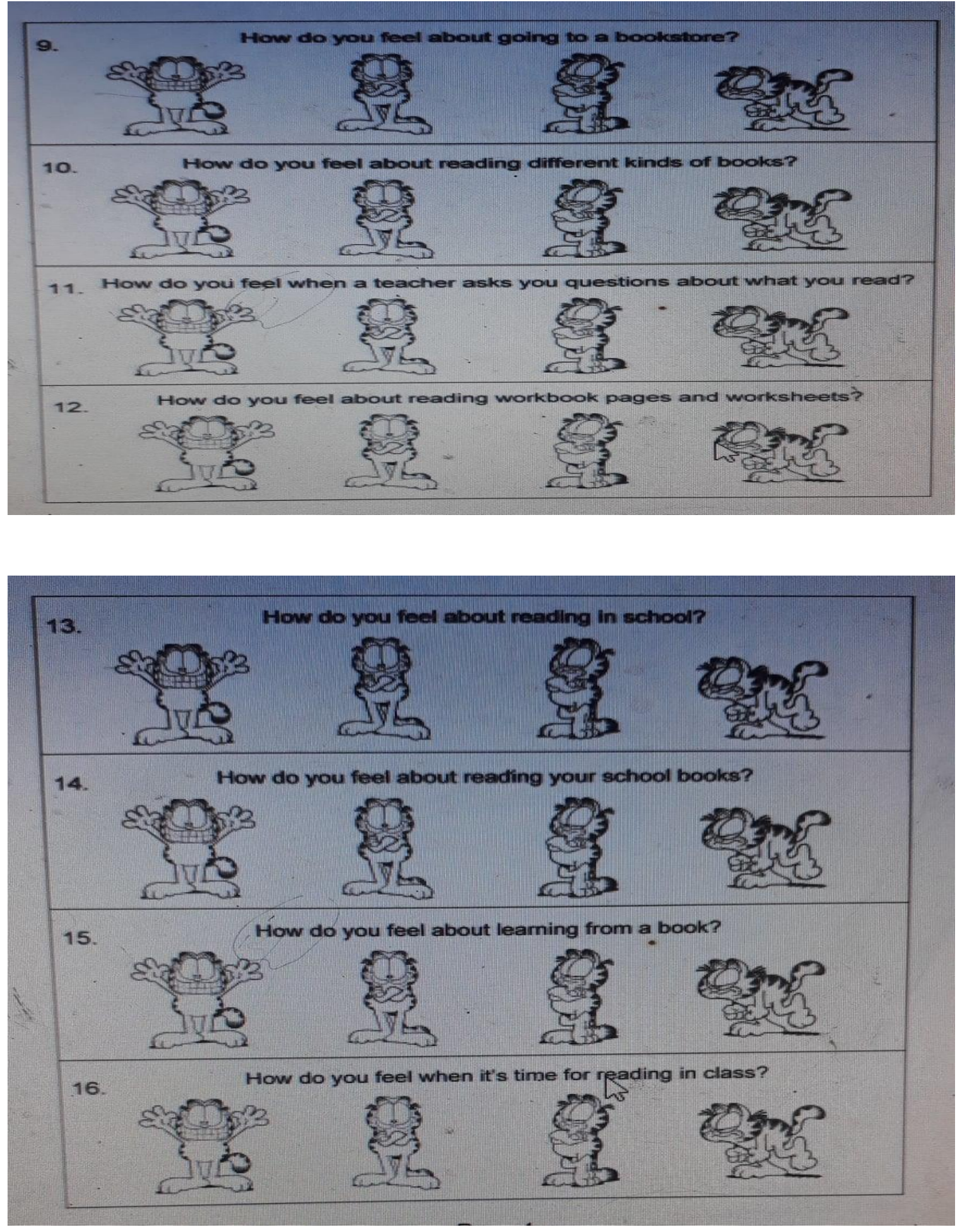


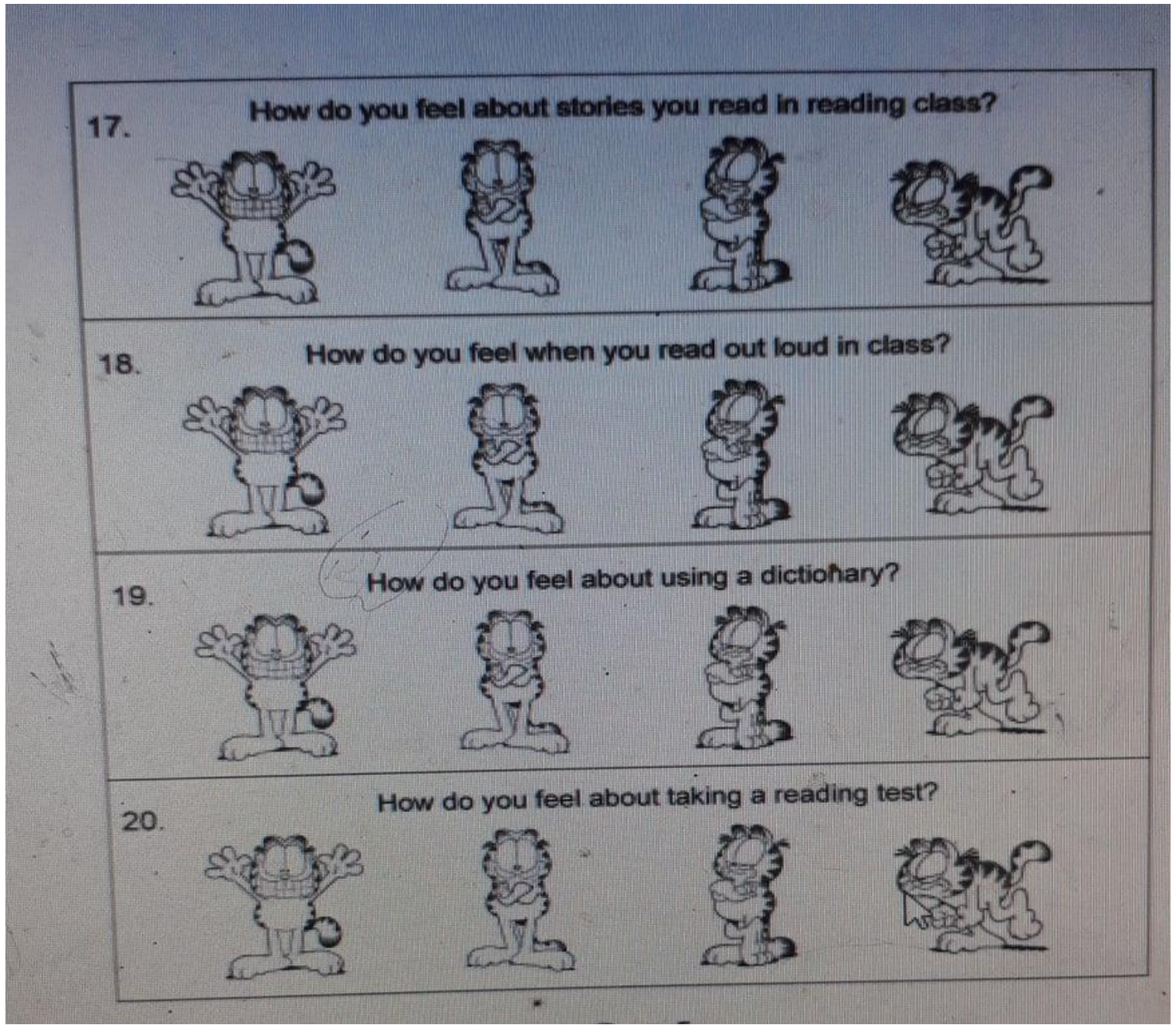

III.Structured Questionnaire for the effect of Modular Learning Approach to Reading Proficiency.

A. Student Interview Questions Name Age

1. Are books available at home?
a. yes
b. no

2. Do you read to someone at home?

a. yes b. no

3. How long do you read at home?

a. never b. a little c. a lot

4. Do your parents read to you at home?

a. yes. B. no

5. How long do your parents read to you at home?

a. never b. a little c. a lot

6. Do your parents talk to about what a story means?

a. yes b. no 
7. Do your parents ask you questions about the pictures?
a. yes
b. no

8. Do your parents ask you what words mean?
a. yes b. no

9. Do your parents ask you what is happening in the story?

a. yes b. no

10. Do you ask your child what is happening in the story?

a. yes b. no

B.Parent Interview Questions

Name Highest Educational Attainment

1. How much time do you spend reading to your child each day? a.never b. 5 minutes c. 10 minutes d. 15 minutes

2. How much time does your child spend reading to you each day?

a.never b. 5 minutes c. 10 minutes d. 15 minutes

3. Are books available at home for your child?

a. yes b.no

4. Do you talk to your child about the meaning of a story?

a. yes b.no

5. When you read do you ask your child questions about the pictures?

a. yes b.no

6. Does your child ask questions about the pictures?
a. yes b.no

7. Does your child look at the pictures and tell a story?
a. yes
b.no

8. Do you ask your child what words mean?

a. yes b.no

9. Does your child ask you what a word means?

a.yes b.no

10.Do you ask your child what is happening in the story?

a.Yes b.no 
C. Open- Ended Questions

1. How do you find Modular Learning Approach and why?

2. Do you think it beneficial to you? Yes or No? Why?

\section{APPENDIX E}

\section{PICTURES WHILE GATHERING DATA}

\section{ST MICHAEL'S COLLEGE}

Iligan City

GRADUATE SCHOOL

Accredited: Philippine Accrediting Association of Schools and Universities (PAASCU)

Appendix E Pictures while Gathering Data
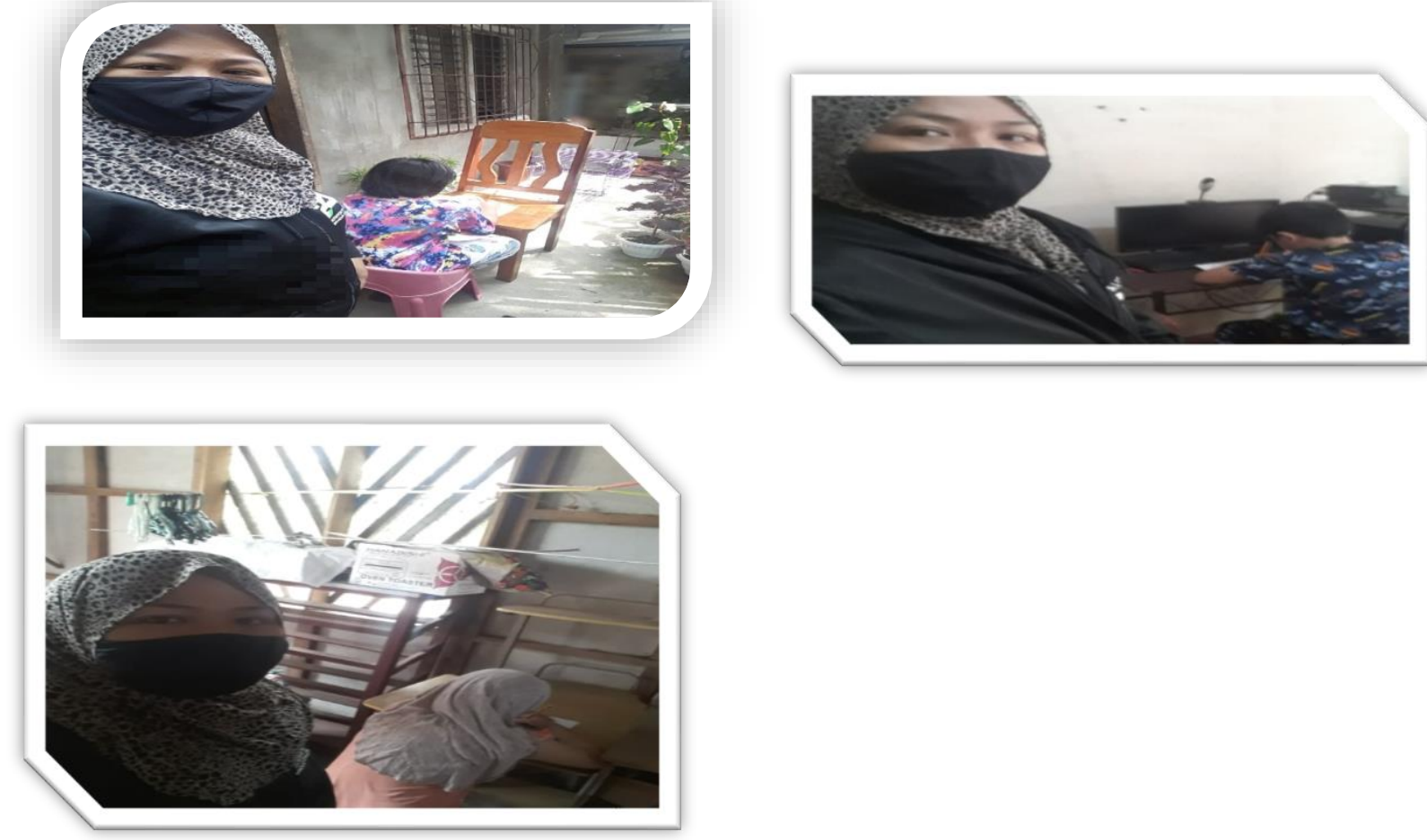


\section{APPENDIX $F$ \\ CERTIFICATE OF DATA GATHERING \\ ST MICHAEL'S COLLEGE \\ Iligan City \\ GRADUATE SCHOOL}

Accredited: Philippine Accrediting Association of Schools and Universities (PAASCU)

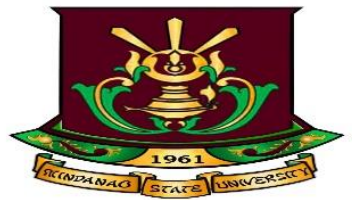

ndanao State University tegrated Laboratory School Irawi City

Certification

This is to certify that the data gathering phase of the research conducted by ASLIMA M. MAROHOMBSAR entitled "MODULAR APPROACH: ITS EFFECT ON LEARNERS' READING ATTITUDE AND PROFICIENCY IN THE NEW NORMAL" tOOK place in Mindanao State University- Integrated Laboratory School on March 8- 12, 2021.

This certification is issued upon the request of the researcher to authenticate the data gathering conducted at Grade 3 pupils of Mindanao State University- Integrated Laboratory School under my approval and supervision. Given this $5^{\text {th }}$ day of April 2021.

Prof. Ebresamen W. Dipatuan

Assistant Dean, MSU- ILS

APPENDIX G

CERTIFICATE OF ORIGINALITY

ST MICHAEL'S COLLEGE

Iligan City

GRADUATE SCHOOL

Accredited: Philippine Accrediting Association of Schools and Universities (PAASCU)

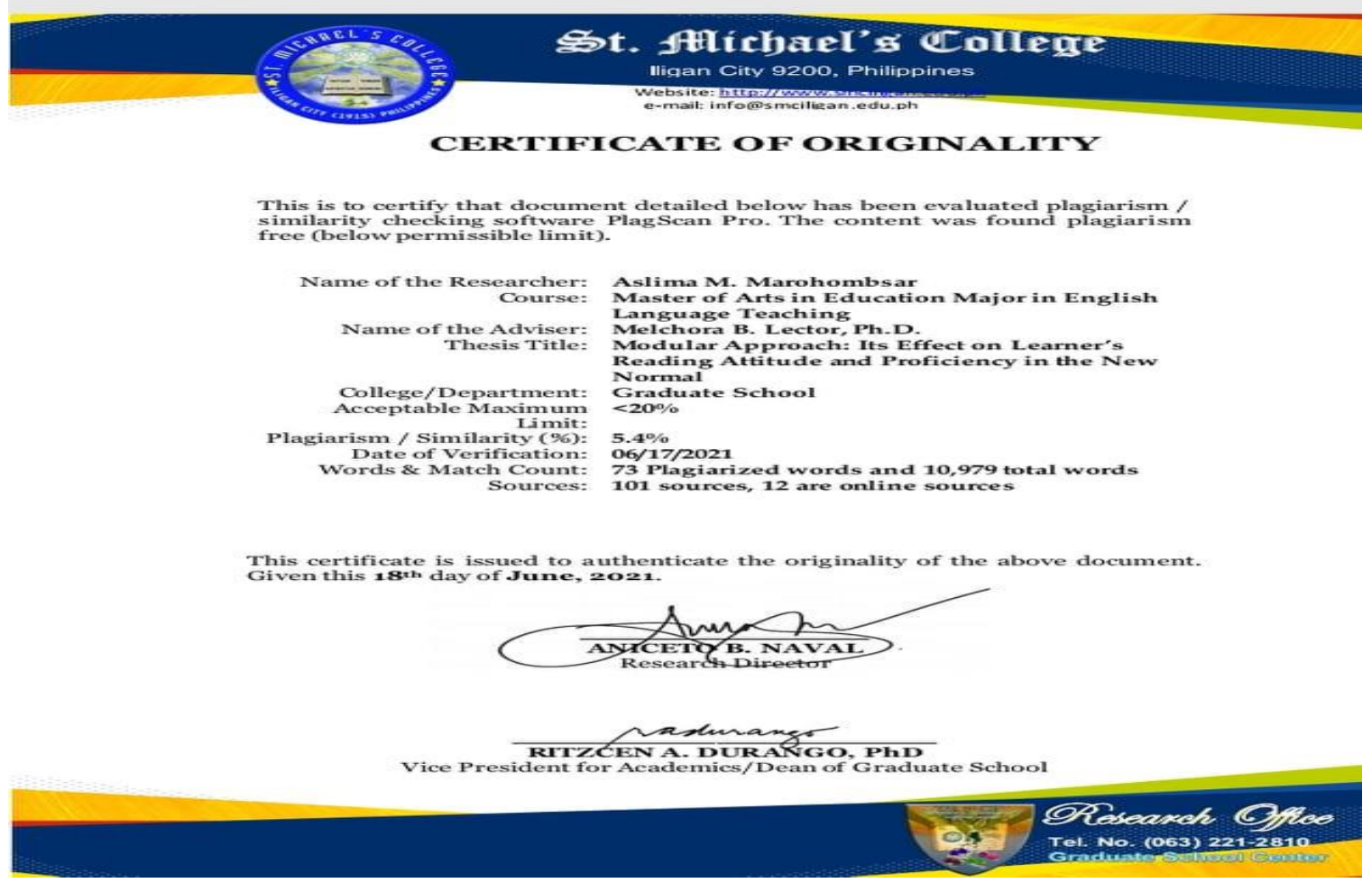

